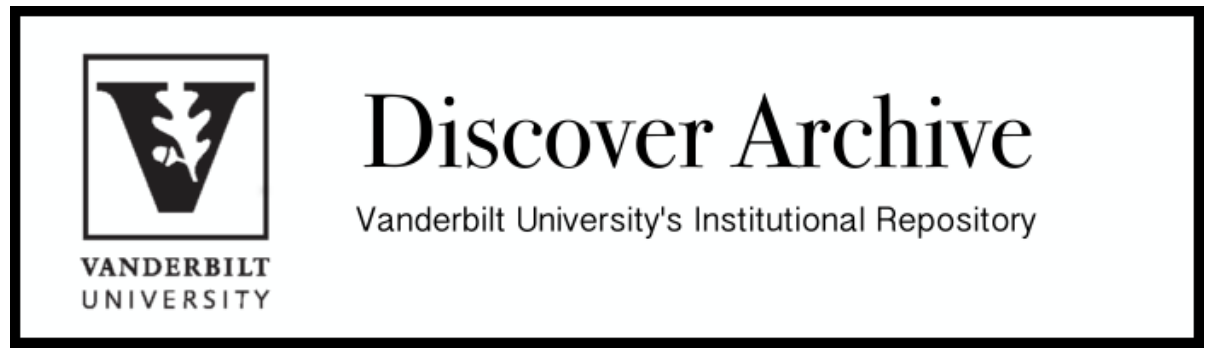

This work was originally published as: Yesha Yadav, The Problematic Case of Clearinghouses in Complex Markets - 101 Georgetown Law Journal 387 (2013). 


\section{HEINONLINE}

Citation: 101 Geo. L.J. 387 2012-2013

Content downloaded/printed from

HeinOnline (http://heinonline.org)

Mon Sep 9 11:42:55 2013

-- Your use of this HeinOnline PDF indicates your acceptance of HeinOnline's Terms and Conditions of the license agreement available at http://heinonline.org/HOL/License

-- The search text of this PDF is generated from uncorrected OCR text.

-- To obtain permission to use this article beyond the scope of your HeinOnline license, please use:

https://www.copyright.com/ccc/basicSearch.do?

\&operation $=$ go\&search Type $=0$

\&lastSearch $=$ simple\&all=on\&titleOrStdNo=0016-8092 


\title{
The Problematic Case of Clearinghouses in Complex Markets
}

\author{
YESHA YADAV*
}

This Article challenges the academic and policy consensus that clearinghouses adequately mitigate the risks of trading credit derivatives. The Article advances two arguments. First, scholars have devoted little attention to the risks posed by underlying assets (such as mortgage loans) that the credit derivative references and the impact that these risks have on the clearinghouse. Credit derivatives enable the economic risk of debt to be separated from the legal rights attaching to that debt. This separation affects the clearinghouse profoundly. As a contract party to each trade it processes, the clearinghouse can be saddled with the economic risk of underlying debt without the legal rights necessary to mitigate its exposure. If a clearinghouse cannot manage its risks, the consequences are invariably systemic and enormously costly to the taxpayer. Second, the Article shows that the clearinghouse's structure exposes its members to complex incentives that (1) encourage risk taking by subsidizing and mutualizing default losses; (2) shift the private costs of monitoring to the clearinghouse and thereby allow members to underinvest in due diligence; and (3) cause members to place undue reliance on information provided by third parties that is often colored by the strategic motives of the parties providing it.

This Article concludes with a proposal for a new paradigm for the clearinghouse. This new model seeks to repair the consequences of separating economic risks from legal rights, which are caused by the use of the credit derivative. It also seeks to mitigate the distorted incentives affecting clearinghouse members. With reforms in place that allow for improved policing of its exposures, the clearinghouse will become a more robust institution that is better positioned to control lax underwriting standards accompanying the extension of credit.

\section{Table of Contents}

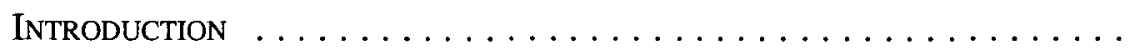

* Assistant Professor of Law, Vanderbilt Law School. (C) 2013, Yesha Yadav. I owe a special debt of gratitude to Professors Christopher Brummer, Edward Cheng, Margaret Blair, Kevin Stack, and Randall Thomas for their extraordinary insights in the preparation of this Article. I thank Professors Robert Ahdieh, William Carney, Christine Desan, Jose Garrido, Adam Levitin, Joseph Norton, Hal Scott, and David Skeel for their comments and thoughtful guidance. I also benefitted greatly from discussions with Owen Lysak, Peter Kerstens, Andrew McCarroll, and Matthew Smith (in their personal capacities) on issues pertaining to this Article, as well as with Dr. Dermot Turing, who provided invaluable insights into the legal, technical, and operational details of clearinghouse functions. Joshua Rabon provided excellent research assistance. I am grateful to the editors of The Georgetown Law Journal for their perceptive insights and thoughtful work on this Article. This Article benefitted greatly from workshops at various law schools in the course of its preparation. All errors are entirely my own. 
I. CLNs, CDSs, AND OTHER WMDs . . . . . . . . . . . 395

A. FINANCIAL INNOVATION AND THE CREDIT REVOLUTION ...... 395

B. AN OVERVIEW OF CREDIT DERIVATIVES . . . . . . . . . . . . 401

1. Credit-Default Swaps . . . . . . . . . . . . . . 402

2. Why Use Credit Derivatives? . . . . . . . . . . 402

II. The Law And Economics of Clearinghouses $\ldots \ldots \ldots \ldots \ldots .406$

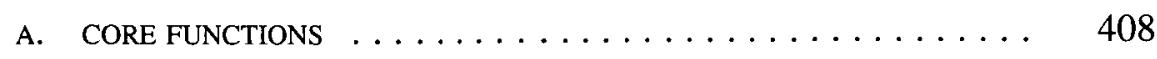

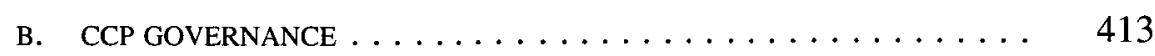

C. INCENTIVES OF CLEARINGHOUSE MEMBERS $\ldots \ldots \ldots \ldots \ldots \ldots, 416$

III. Reevaluating the Regulatory Paradigm . . . . . . . . . 420

A. COORDINATION AND INFORMATION ASYMMETRIES $\ldots \ldots \ldots \ldots 420$

1. Assumption One: Information Must Be Useful and Comprehendible ................. 421

2. Assumption Two: Information Must Be Used Rationally . . . . . . . . . . . . . . . . . 426

B. CCP AND DEBT GOVERNANCE $\ldots \ldots \ldots \ldots \ldots \ldots \ldots .427$

C. THE COST OF INCENTIVE RISKS $\ldots \ldots \ldots \ldots \ldots \ldots \ldots .431$

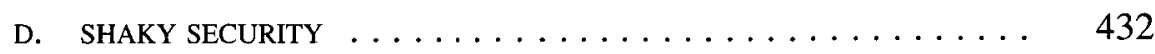

IV. Reconceptualizing the Paradigm: The Clearinghouse REFORMED . . . . . . . . . . . . . . . . . 434

A. INFORMATION ASYMMETRIES $\ldots \ldots \ldots \ldots \ldots \ldots \ldots \ldots$

B. DEBT gOVERnANCE . . . . . . . . . . . . . . . . . 439

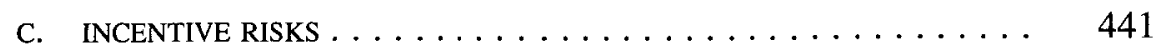

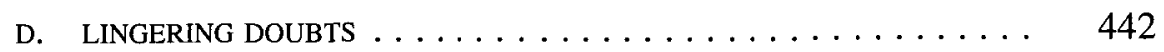

Conclusion ................................ 444

\section{INTRODUCTION}

Following the 2008 financial crisis, the extraordinary risks posed by credit derivatives have met with conventional regulatory responses. Commentators urged $^{1}$ - and regulators acted ${ }^{2}-$ to move credit derivative transactions onto

1. See, e.g., Craig Pirrong, The Economics of Clearing in Derivatives Markets: Netting, Asymmetric Information, and the Sharing of Default Risks Through a Central Counterparty (Univ. of Houston, Working Paper, 2009), available at http://papers.ssrn.com/sol3/papers.cfm?abstract_id=1340660. For an informative discussion, see Darrell Duffie \& Haoxiang Zhu, Does a Central Clearing Counterparty Reduce Counterparty Risk?, 1 Rev. AsseT PRICING STUD. 74, 74-75 \& n.1 (2011) (discussing the 
exchanges, and they deployed clearinghouses to settle trades. This Article challenges the current regulatory and academic consensus and argues that clearinghouses, as presently conceived, are sorely ill-equipped to contend with the complex legal and economic risks of the credit derivative. ${ }^{3}$

Clearinghouses are stitched into the fabric of the financial markets and intrinsic to their operation. Relied upon by nearly all prominent exchanges, including the New York Stock Exchange, NASDAQ, and the Chicago Mercantile Exchange, as well as international marketplaces like the London Stock Exchange and Deutsche Börse, they process and settle several trillion dollars in trades daily. ${ }^{4}$

novation requests received by large dealer banks who legally stood between Bear Stearns and its contract parties, thus acting as de facto clearinghouses by controlling the spread of risk through the markets); Bryan Burrough, Bringing Down Bear Stearns, VANITY FaIR, Aug. 2008, at 106, 151 (reporting on the rumors regarding Bear Stearns's solvency and reactions to those rumors, including the large volume of novation requests sent to Goldman Sachs and Deutsche Bank); Kate Kelly, Fear, Rumors Touched off Fatal Run on Bear Stearns, WALL St. J., May 28, 2008, http://online.wsj.com/article/ SB121193290927324603.html (reporting on the flood of novation requests received by the likes of Goldman Sachs and Deutsche Bank that were sometimes accepted but for larger fees than usual).

2. G-20 Pittsburgh Summit, Leaders' Statement: The Pittsburgh Summit 7 (2009), available at http://ec.europa.eu/commission_2010-2014/president/pdf/statement_20090826_en_2.pdf ("All standardized OTC derivative contracts should be traded on exchanges or electronic trading platforms, where appropriate, and cleared through central counterparties by end-2012 at the latest."). Some scholars, however, have raised concerns regarding clearinghouses. E.g., Duffie \& Zhu, supra note 1, at 76 (examining the subject from a financial-theory perspective and showing that clearinghouses are only likely to reduce counterparty risks when the number of clearing members is sufficiently large to support multilateral netting relative to the value of bilateral exposures in the OTC market); Pirrong, supra note 1, at 4-5 (noting that the formation of a CCP will not necessarily result in "positive net benefits for derivatives markets participants"); Mark Roe, Clearinghouse Over-Confidence, ProJect SYNDICATE (Oct. 26, 2011), http://www.project-syndicate.org/commentary/roe6/English (noting risks of clearinghouses, including that instead of simply absorbing risk, the clearinghouse transfers it among its individual members, and when these institutions fail, the effects are felt across the market systemically); see also All Clear?, EConomist, Apr. 7, 2012, http://www.economist.com/node/21552209; Clear and Present Danger, Economist, Apr. 7, 2012, http://www.economist.com/node/21552217; Gillian Tett, Insight: The Clearing House Rules, Fin. Times, Nov. 5, 2009, http://www.ft.com/cms/s/0/5874e922-cald11de-a5b5-00144feabdc0.html.

3. For more detail, see John W. McPartland, Fed. Reserve Bank of Chi., Clearing and Settlement DEMYSTIFIED 3 (2005), available at http://www.chicagofed.org/digital_assets/publications/chicago_fed_ letter/2005/cfjanuary2005_210.pdf. Some types of derivatives are widely traded on public markets and cleared through clearinghouses. Examples include futures and options contracts, referenced to a wide spectrum of underlying assets such as commodities or equities. Specialist derivatives exchanges include, for example, the Chicago Mercantile Exchange, Eurex, Globex, and the London Metal Exchange. In addition to exchanges, clearinghouses are involved in clearing the derivative products traded on exchanges. Clearinghouses include LCH.Clearnet, which is a London- and Paris-based clearinghouse for a wide variety of derivative products originating on a number of international exchanges. In the United States, the Chicago Mercantile Exchange, the Chicago Board of Trade, and the New York Mercantile Exchange operate their own clearinghouse under the banner of the CME Group called CME Clearing. See Clearing, CME GRP., http://www.cmegroup.com/clearing/ (last visited Oct. 12, 2012).

4. For example, in 2010, the Depository Trust and Clearing Corporation (DTCC), a leading clearinghouse that provides clearing, settlement, and securities-depository services for major U.S. exchanges, reported settling over one-quadrillion-dollars worth of trades through its subsidiaries. Transaction Statistics and Performance, DePOSTTORY Trust \& ClearING CoRP., http://www.dtcc.com/about/ 
Historically, credit derivatives-contracts to buy and sell the credit risk attached to an underlying asset such as a loan or basket of bonds-have traded directly between sophisticated financial firms rather than on exchanges. By virtue of deregulation, ${ }^{5}$ their dealings have taken place largely outside of federal oversight in the so-called over-the-counter (OTC) market for securities. ${ }^{6}$ As witnessed in the 2008 crisis and the May 2012 J.P. Morgan debacle, ${ }^{7}$ credit derivatives can involve enormous risks to financial firms and the real economy,

business/statistics.php (last visited Jan. 15, 2012) (reporting settlement of $\$ 1.66$ quadrillion in trades for 2010 ). CME Clearing reports that it monitors and processes approximately $\$ 1$ quadrillion in trades on an annual basis. Clearing, supra note 3.

5. See Commodities Exchange Act, 7 U.S.C. \& 2(g) (2006) (excluding swap transactions from regulation under the CEA); Commodity Futures Modernization Act, Pub. L. No. 106-554, 114 Stat. 2763, 2763A-365 to -480 (2000). The Commodity Futures Modernization Act of 2000 allowed derivatives to be traded outside of exchanges and clearinghouses, thereby placing them beyond the scope of federal oversight. The literature has highlighted a variety of factors that fueled the growth of unregulated derivatives markets, including the prevailing deregulatory mood in Washington, successful lobbying efforts, and concerns that U.S. capital markets were losing their competitive edge to European financial centers. For an illuminating discussion of the political context, see Roberta S. Karmel, The Future of the Securities and Exchange Commission as a Market Regulator, 78 U. CIN. L. REv. 501 (2009) (providing historical analysis of the policy debates surrounding regulation of derivatives); Lynn A. Stout, Why the Law Hates Speculators: Regulation and Private Ordering in the Market for OTC Derivatives, 48 DUKE L.J. 701 (1999) (discussing the trend towards deregulation in the late 1990s and the subsequent failure to implement common law principles to prevent speculation in the context of OTC derivatives, which gave rise to bubbles and trading losses). See also Eric Lipton, Gramm and the 'Enron Loophole,' N.Y. TiMEs, Nov. 17, 2008, http://www.nytimes.com/2008/11/17/business/17gramm side.html (reporting on language in the Commodity Futures Modernization Act that Enron had advocated for, which largely exempted the company from regulation of its energy trading on electronic commodity markets).

6. In an OTC market, parties can transact with one another directly. In such markets, they benefit from the ability to negotiate and structure deals to their own specific needs and determine how best to allocate the risk among themselves. This means that parties decide what kind of security should support the deal, the triggers for enforcement, and how the deal (and its risk) should be priced. While this freedom allows parties to innovate and create profitable, intricate transactional structures, it also carries with it the danger that these dealings can go unchecked. Industry groups have developed mechanisms to create some uniformity among the OTC contracts used by parties in the derivatives markets (so the contracts have common clauses for what kinds of security are acceptable, when loss-mitigation tools will be triggered, and how events of defaults in OTC markets should be handled). Notable in this regard are the Master Agreements developed by the International Swaps and Derivatives Association (ISDA), the International Capital Market Association (ICMA), and the International Securities Lending Association (ISLA). For an analysis of the ISDA Master Agreement, see Bushan K. Jomadar, The ISDA Master Agreement-The Rise and Fall of a Major Financial Instrument (Westminster Bus. Sch.; Univ. of Westminster Sch. of Law, Working Paper, 2007), available at http://papers.ssrn.com/sol3/papers.cfm? abstract_id $=1326520$ (noting that the ISDA Master Agreement has created legal certainty through contractual standardization in the OTC-derivatives market). See also Frank Partnoy, ISDA, NASD, CFMA, and SDNY: The Four Horsemen of Derivatives Regulation? 1-11 (Univ. of San Diego Sch. of Law, Working Paper No. 39, 2002), available at http://papers.ssrn.com/sol3/papers.cfm?abstract_ id $=293085$ (discussing, among other things, the development of private rules for the regulation of derivatives through ISDA and the strong trend towards private regulation of derivatives as a means of preventing regulatory arbitrage).

7. See Tom Braithwaite, JPMorgan Blames 'Bad Judgment' for $\$ 2 b n$ Hit, Fin. Times, May 11, 2012, at 1 (discussing the extensive losses suffered by J.P. Morgan in the credit-default-swap (CDS) market). 
all with little warning and few means of risk mitigation. ${ }^{8}$ From this perspective, it makes considerable sense to bring these transactions into the light of day and onto exchanges, allowing clearinghouses to mitigate the risks that arise among market participants.

A clearinghouse brings together the largest financial firms to reduce counterparty trading risks and to share losses. ${ }^{9}$ It fulfills the following functions: to (1) confirm the details of transactions executed on an exchange ${ }^{10}$ and ensure that they are processed to completion; ${ }^{11}$ (2) mitigate the risk of counterparty default; and (3) share risk and losses among members of the clearinghouse. Key to achieving these goals is the clearinghouse that acts as a central counterparty (CCP). ${ }^{12}$ Legally, the clearinghouse breaks open the contract between a seller and a buyer of securities, interceding to become the buyer to each seller and the seller to each buyer so that each party only has to transact with the clearinghouse. ${ }^{13}$ By becoming the legal counterparty to each trade, the clearinghouse minimizes idiosyncratic risks attaching to specific firms and thus

8. Michael S. Barr, The Financial Crisis and the Path of Reform, 29 YALE J. on Reg. 91 (2012) (analyzing the OTC-derivatives market and highlighting the use of clearinghouses under the DoddFrank Act to mitigate that market's risks); Lynn A. Stout, The Legal Origin of the 2008 Financial Crisis (UCLA Sch. of Law, Paper No. 11-05, 2011), available at http://papers.ssrn.com/sol3/papers.cfm? abstract_id $=1770082$ (arguing that deregulation of the OTC-derivatives markets under the Commodity Futures Modernization Act of 2000 was one of the key causes leading to the 2008 financial crisis); Michael Barr, Professor, Univ. of Mich. Law Sch., Speech to the Pew/NYU Stern Conference on Financial Reform: The Dodd-Frank Act, One Year On (June 27, 2011) (transcript available at http://blogs.law.harvard.edu/corpgov/2011/07/21/the-dodd-frank-act-one-year-on/) (discussing the growth of the shadow banking system in the run-up to the financial crisis and its impact on the growth of leverage and the real economy). For an argument that credit derivatives did not play a meaningful causative role in the financial crisis, see René M. Stulz, Credit Default Swaps and the Credit Crisis, 24 J. ECON. PERSP. 73 (2010) (analyzing the challenges in valuing credit derivatives, but noting that their contribution to the crisis is not straightforward).

9. Commentators argue that that the development of a central counterparty arose on account of strong regulatory pressure despite industry resistance. Pirrong, supra note 1 , at 5 (explaining that market participants "prefer[red] the incumbent method for sharing default risks to sharing them through a CCP"). For further detail, see Craig Pirrong, If It's so Great ..., Streetwise Professor (Nov. 22, 2008, 5:03 PM), http://streetwiseprofessor.com/?p=984.

10. Clearinghouses can also complete trades that are executed in the OTC market. For an in-depth account of the operational and legal features of clearinghouses and how these can vary by jurisdiction, as well as national approaches to clearing and settlement, see Dermot Turing, Clearing And SetTleMENT IN EUROPE (2012).

11. Clearinghouses settle trades as part of their functions. Generally, this requires that a seller of securities receive cash for her securities and the buyer receive the securities subject to the sale.

12. Not all clearinghouses adopt the CCP model. Clearinghouses can also operate using a principalto-principal model whereby large firms transact with each other directly-just like on an OTC market. The London Metal Exchange, for example, functioned without a CCP until the Tin Crisis in 1985 and 1986 when tin prices suddenly collapsed and exchange members suffered huge losses as a result, with many contracts defaulting at once. However, the CCP model has increasingly come to be seen as an international standard for the purposes of risk mitigation and has proliferated across international markets. See Pirrong, supra note 1; Comm. on Payment \& Settlement Sys., Bank for Int'L Settlements, Recommendations for Central Counterparties 1-3 (2004).

13. As explained in this Article, the clearinghouse achieves this by novating the contract of each leg of the trade to itself. In a novation, Party $A$ transfers the rights and obligations in its contract with Party $B$ to the clearinghouse and Party $B$ does the same. Novation differs from an assignment. In an 
enables parties to transact with a (seemingly) safe and reliable partner-the clearinghouse. ${ }^{14}$ As key infrastructure for the market, the clearinghouse obtains privileged insight into the market's movements. In monitoring trades, the clearinghouse mandates that its members continually set aside sufficient capital to support the risks that those members run. ${ }^{15}$ Importantly, if a member becomes insolvent and cannot pay out on its obligations, the clearinghouse shares the losses among its remaining solvent members, preventing systemic catastrophe in the market.

Despite their importance, clearinghouses and the conditions necessary to ensure their proper operation are undertheorized. Two areas of regulatory complexity have not been subject to critical examination. First, the literature has devoted little attention to how the risks carried by underlying assets (such as a pool of mortgage loans) that the credit derivative references distort clearinghouse functions. Underlying assets like mortgage pools or bonds present considerable risks for the clearinghouse. ${ }^{16}$ For example, the credit quality of loans or bonds is only as good as the diligence that the creditor extending them has conducted. If creditors are reckless, then these loans are primed for failure. ${ }^{17} \mathrm{As}$ a CCP, the clearinghouse must contend with these deeper economic risks and ensure that it possesses the financial and legal resources necessary to safeguard

assignment, contract rights are transferred to an assignee-but not the burdens. In a novation, the party taking over a contract assumes both the benefit and the burden of the contract.

14. If Firm $A$ is undertaking a transaction with Firm $B$ and is unsure of the risk that it is assuming, then it should, ideally, set aside spare capital to provide for this risk. The amount of capital it keeps will be based not only on the risk of the transaction but also on the added uncertainty of $B$ 's solvency. $A$ may be advised to keep capital to account for the risk of the transaction until the transaction comes to an end (in case, owing to default, it terminates early and without warning). With a clearinghouse and $\mathrm{CCP}, A$ no longer needs to worry about the risk of $B$ defaulting. Furthermore, the clearinghouse monitors the transaction on an ongoing basis, so the initial capital that $A$ sets aside can be lower than what it would be otherwise.

15. E.g., CME RulEbook, CME Group, rr. 8H04(2)-(3), 8H10, available at http://www.cmegroup. com/rulebook/CME/L/8H/8H.pdf (requiring members to maintain scalable minimum-capital amounts); Clearing House: General Regulations, LCH.Clearnet, at Regulation 12, available at http://www.lchclear net.com/Images/General\%20Regulations_tcm6-43737.pdf (reciting necessary coverage for collateral requirements).

16. As evidenced in the 2008 crisis, underlying assets such as mortgages and mortgage-backed securities were highly correlated. This means that, owing to the downturn affecting the real estate market, many borrowers defaulted on their mortgages during the same time period which set off losses on the mortgage-backed securities that referenced these mortgages. For detail on the intensifying impact of correlated losses in the crisis, see Viral V. Acharya \& Matthew Richardson, Causes of the Financial Crisis, 21 Critical Rev. 195 (2009).

17. As demonstrated in the 2008 crisis, creditors that are able to sell off the risk of loans taken on using techniques such as securitization or instruments such as credit derivatives have limited incentives to exercise diligence in underwriting. This means that they may make bad loans, knowing that the economic risk of these loans can be sold on to those who are willing to buy and hold that risk. See infra Part I; see also Adam J. Levitin \& Susan M. Wachter, Explaining the Housing Bubble, 100 GEo. L.J. 1177 (2012) (showing that the growth of the housing bubble in the run-up to the 2008 financial crisis may be attributable to incorrectly priced mortgage finance and arguing that the availability of a market in mortgage-backed securities and information asymmetries in the financial markets skewed the price and availability of mortgage finance). 
against their worst excesses. ${ }^{18}$ Second, from an institutional perspective, while commentators acknowledge that clearinghouses concentrate systemic risk in the market, ${ }^{19}$ the fuller regulatory risks posed by and to this institution remain thinly explored. Specifically, clearinghouse members share the risk of losses with other members. This risk-sharing function works to underwrite and diversify the risk that member firms assume. If one member takes on too much risk and fails, other members must bear the cost. ${ }^{20}$ This Article posits that this risk-sharing function can lead to misaligned incentives where individual participants trade knowing that, ultimately, the clearinghouse will bear the costs of their risk taking. In view of this "subsidy value" provided by the clearinghouse, individual market participants using the clearinghouse may be motivated to undertake risky but privately profitable trades because the clearinghouse is ultimately on the hook to complete the transaction. Parties using the clearinghouse, therefore, are primed to seek out ways to exploit the clearinghouse's risk-sharing function and carry out high-risk-yet underwritten-trades. Members' distorted incentives can thus lead to behavior that increases the chances that the clearinghouse itself descends into crisis.

This Article provides a new regulatory critique of the role of the clearinghouse in the modern marketplace. It proposes that, in its role as CCP, the clearinghouse must contend with the main challenge of the credit derivativethe credit derivative's ability to separate the economic interest of debt from the legal rights that frame that interest. ${ }^{21}$ As detailed in Part I, a credit derivative allows Party $A$ to trade away its economic risk of loss on a loan or a bond to Party $B$. In this way, a credit derivative separates the economic interest in a loan or a bond from the legal rights attaching to that interest. ${ }^{22}$ From a transactional perspective, by becoming the central contract party to credit-

18. For insights from finance theory on credit derivatives and their complexity, see Pirrong, supra note 1, at 12 (explaining that, in the cases of Lehman Brothers and Bear Stearns, losses on CDSs derived from losses affecting mortgage-backed securities).

19. See, e.g., Comm. on Capital Mkts. Regulation, The Global Financial Crisis: A Plan for REGULATORY REFORM 48 (2009) [hereinafter CCMR Report], available at http://www.capmktsreg.org/pdfs/ TGFC-CCMR_Report_\%285-26-09\%29.pdf (acknowledging that "these mega-concentrations of counterparty risk would demand vigilant regulatory oversight").

20. Pirrong, supra note 1 , at 3-4, 16-17 (discussing the wealth-transfer and loss-sharing functions of clearinghouses).

21. See Frank Partnoy \& David A. Skeel, Jr., The Promise and Perils of Credit Derivatives, 75 U. Cin. L. Rev. 1019 (2007) (providing an illuminating analysis of the credit derivative by chronicling its use and analyzing its risks—such as increasing moral hazard-in modern markets).

22. Party $A$ may be a bank that has extended a loan and wishes to hedge that risk or an investor in bonds who does not want to hold any exposure to the issuer. For an interesting essay on informally conceiving of credit derivatives as insurance, see M. Todd Henderson, Credit Derivatives Are Not "Insurance," 16 ConN. INs. L.J. 1, 4 (2009) (arguing that credit derivatives should not be regulated as insurance contracts). Under the Dodd-Frank Act, credit-default swaps are expressly excluded from the definition of an "insurance contract" for the purposes of regulation under state law. Dodd-Frank Wall Street Reform and Consumer Protection Act, Pub. L. No. 111-203, § 767(a)(4), 124 Stat. 1376, 1800 (2000) (codified as amended at 15 U.S.C. $\S 78 \mathrm{bb}(\mathrm{a})(4)$ (2006 \& Supp. V)) [hereinafter Dodd-Frank Act]. 
derivative trades, the clearinghouse can be left saddled with the vast economic risk carried by underlying assets without the legal tools necessary to mitigate this risk, giving rise to what is termed here as the "derivatives deficit." The clearinghouse faces a multitude of hazards owing to the play of the derivatives deficit: (1) it does not obtain sufficient information to understand its risks in the transaction chain from underlying asset to credit derivative; (2) it is unable to act ex ante to discipline dangerous firms throughout the transaction chain that are behaving recklessly and externalizing the costs of their actions to the clearinghouse; (3) it becomes embroiled in unfamiliar legal process and procedure (such as matters of debt governance where it holds economic interest in debt or in garnering a way to exert influence on debtor entities via its interest); ${ }^{23}$ and (4) it confronts the incentives of its own members who may be tempted to take high risks for private gain using credit derivatives, especially when the gains may come at the expense of the clearinghouse. Accordingly, without a fuller picture of the exposures it faces, the clearinghouse is unable to properly provision for and manage its own risks, notably through collateral cushions, position limits, or timely discipline of its members.

In its normative contribution, this Article recognizes that clearinghouses will likely remain central to the architecture of derivatives markets despite the risks they pose to the financial system. With this perspective, the Article proposes a solution to strengthen the clearinghouse by curing the derivatives deficit. Briefly, the Article suggests that clearinghouses be permitted to formally engage with a wide cohort of market actors, not just the small cohort of financial firms that constitute its membership. This proposal allows the clearinghouse to get fulsome information on underlying exposures from a wide spectrum of firms, to monitor and discipline these market players for reckless behavior, and to get legal recognition of its economic exposures on underlying debt in insolvency proceedings. More broadly, this proposal derives motivation from the policy pull of reducing moral hazards pervasively seen in lax lending standards in the market. This Article goes on to suggest that, with stronger legal tools, the

23. See Kenneth Ayotte \& David A. Skeel, Jr., Bankruptcy or Bailouts?, 35 J. CoRP. L. 469, 470-71 (2010) (discussing the regulatory and governance implications arising in the application of Chapter 11 to financial institutions and noting the challenges in restructuring of financial institutions under Chapter 11); Douglas G. Baird \& M. Todd Henderson, Other People's Money, 60 Stan. L. Rev. 1309, 1311-12 \& n.14 (2008) (discussing the blurred line between debt and equity, especially with regards to credit-default swaps, and stating that, because slices of debt can be sold to a number of investors, credit-default swaps increasingly are exhibiting equity-like characteristics); George G. Triantis \& Ronald J. Daniels, The Role of Debt in Interactive Corporate Governance, 83 CALIF. L. REv. 1073, 1080-81 (1995) (examining the roles of the bank as a governance player and debt as a governance instrument). For a perspective on the role of hedge funds in corporate governance, see Alon Brav et al., Hedge Fund Activism, Corporate Governance, and Firm Performance, 63 J. FIN. 1729, 1730-31 (2008) (providing large-scale empirical data on the role of hedge funds in corporate governance that show that hedge fund investors and shareholders offer strategic and financial remedies to target companies); Marcel Kahan \& Edward B. Rock, Hedge Funds in Corporate Governance and Corporate Control, 155 U. PA. L. Rev. 1021, 1026-27 (2007) (discussing the implications of activist hedge-fund shareholders for corporate governance). 
clearinghouse can persuade market actors-beyond simply clearinghouse members-to refrain from acting on distorted incentives that exacerbate existing credit risk in the market. Recognizing that clearinghouse members are subject to perverse incentives of their own, this Article suggests that the accountability and reputational pressures created under this new paradigm will serve to align the incentives of clearinghouse members with the larger policy goal of achieving systemic safety in financial markets. Though clearinghouses are volatile and imperfect institutions, the broader policy argument for the clearinghouse's greater intervention is central to achieving, ultimately, the goal of market safety. This is not just from the perspective of institutional self-preservation. More broadly, this policy argument reflects commitment to a mechanism designed to improve lending standards within the market and the real economy.

This Article is structured as follows: Part I explains the economic and legal complexity of credit derivatives; Part II fully explores the legal and economic foundations of the clearinghouse; Part III analyzes the legal and institutional risks that the clearinghouse faces when clearing complex derivatives; and Part IV sets out a solution to remedy these key risks and, notably, the externalities generated by the derivatives deficit in clearing.

\section{CLNs, CDSs, AND OTHER WMDs}

\section{A. FINANCIAL INNOVATION AND THE CREDIT REVOLUTION}

The humble bank loan has undergone a revolution. Whereas once such loans might have come to rest on bank books, innovations in financial engineering have seen these loans transform into lucrative commodities in the financial markets. The financial alchemy that turns loans into securities reshapes the economic characteristics of loans as well as their underlying legal relationships and incentives. This section details this revolution. It first provides a primer on the securitization process and its regulatory implications for the bank-borrower relationship. Then, it moves to an overview of the key economic and legal characteristics of credit derivatives to link together the transaction chain that leads from Main Street to the complex world of credit derivatives.

Securitization has increased in economic and social significance since the process was first introduced in the $1960 \mathrm{~s}^{24}$ Over the following few decades, it spawned a market worth several trillion dollars in the United States alone and transformed the legal and economic characteristics of traditional lending. ${ }^{25}$

24. See, e.g., Frank J. Fabozzi \& Vinod Kothari, Securitization: The Tool of Financial Transformation, 20 J. Fin. Transformation 33, 34 (2007).

25. Protecting Homeowners: Preventing Abusive Lending While Preserving Access to Credit: Hearing Before the Subcomm. on Fin. Insts. \& Consumer Credit and the Subcomm. on Hous. \& Cmty. Opportunity of the H. Comm. on Fin. Servs., 108th Cong. 93 (2003) (statement of Cameron L. Cowan, Chairman, Legislative \& Judicial Subcomm., American Securitization Forum). The discussion on the disconnect between economic exposure and the legal rights that frame it flows out of the seminal work 
Prior to its development, the bank-borrower relationship inhabited a fairly standard legal and economic structure. One of the defining features of this design was that banks held loans on their balance sheets until maturity. Because the bank held the loan until term, the bank needed to be mindful of the credit risk that it was taking on ex ante. Banks could protect themselves against the credit risk in three important ways: (1) extending loans to borrowers that were most likely to repay; (2) holding reserves of capital to match the risk assumed on the loans; ${ }^{26}$ or (3) relying on deposit lending as the main source of funding for extending loans, meaning a natural ceiling existed on the amounts that could be loaned out. ${ }^{27}$ In addition to its contract with the borrower, the bank could also rely on protections offered by the insolvency process to preserve the value of its investment in the borrower. For example, the bank could take and enforce a security interest in the borrower's assets or, alternatively, where a loan remained viable, push for a restructuring of its obligations with the borrower. ${ }^{28}$ Given the risk taken on their books and the length of time that the risk would be held, banks had incentives to pursue these routes whenever possible.

Securitization has transformed this standard bank-borrower relationship. In short, ${ }^{29}$ the process works as follows: ${ }^{30}$ Banks make loans (for example, mortgage loans) ${ }^{31}$ that they then remove from their balance sheets by selling them to an off-balance sheet special purpose entity (SPE). This entity then

by Professors Hu and Black in their analysis of debt decoupling. Their discussion of this issue and the governance implications of this phenomenon are set out in a series of papers, notably Henry T.C. Hu \& Bernard Black, Equity and Debt Decoupling and Empty Voting II: Importance and Extensions, 156 U. PA. L. Rev. 625 (2008) [hereinafter Hu \& Black, Equity], and Henry T.C. Hu \& Bernard Black, Hedge Funds, Insiders, and the Decoupling of Economic and Voting Ownership: Empty Voting and Hidden (Morphable) Ownership, 13 J. CoRP. Fin. 343 (2007) [hereinafter Hu \& Black, Hedge Funds]. From a financial-theory perspective, the separation between economic and legal interest, as enabled by credit derivatives, has also received attention. See Patrick Bolton \& Martin Oehmke, Credit Default Swaps and the Empty Creditor Problem, 24 REv. FIN. STUD. 2617 (2011) (examining the empty creditor problem from a formal financial model).

26. See Richard Scott Carnell et al., The Law of Banking and Financial Institutions ch. 5 (4th ed. 2009).

27. See Biagio Bossone, What Makes Banks Special? A Study of Banking, Finance, and Economic Development 6-9 (World Bank, Working Paper No. 2408, 1999) (analyzing the role that banks play in supplying credit and liquidity); Daniel Tarullo, Fed. Reserve Governor, Address at the North Carolina Bankers Association Annual Convention: Large Banks and Small Banks in an Era of Systemic Risk Regulation (June 15, 2009) (transcript available at http://www.federalreserve.gov/newsevents/speech/ tarullo20090615a.htm) (discussing the impact of systemic risk regulation on large and small banks). This practice of holding demand deposits while extending longer term loans to borrowers creates a maturity mismatch for banks that increases the possibility of runs on the bank. See CARNELL ET AL., supra note 26 , at $46-47$.

28. See Thomas H. Jackson, The Logic and Limits of Bankruptcy Law 8-9 (1986).

29. For an in-depth account, see Adam B. Ashcraft \& Til Schuermann, Fed. Reserve Bank of N.Y., Rep. No. 318, Understanding the Securitization of Subprime Mortgage Credit 13-23 (2008).

30. This brief outline applies to a private-label securitization where the securitization is not undertaken by a government-sponsored entity such as Fannie Mae or Freddie Mac.

31. Mortgage loans have provided a substantial asset base for the securitization market. It has been estimated that just prior to the onset of the 2006 crisis, approximately $\$ 8.6$ trillion of securitized mortgage debt was outstanding, compared to $\$ 4.9$ trillion of U.S. Treasury securities and $\$ 5.4$ trillion in 
issues bond securities to investors at-large in the financial markets. Investors derive returns from these securities via the income generated by the pools of underlying assets such as mortgages, car loans, or credit-card receivables. As borrowers repay their loans, this money funds payments to investors in these so-called asset-backed securities. By purchasing securities issued by the SPE, investors also come to share the risk of these bank loans. Thus, if borrowers default on the underlying loans or otherwise fail to fulfill their repayment obligations, investors lose out. ${ }^{32}$ Finally, banks selling their loans in a securitization receive upfront payment for the loans from investors. Lenders can then use this influx of funds to make a fresh set of loans to new borrowers (which, in turn, can be securitized and sold off the balance sheet thereby restarting the cycle).

Scholars agree that securitization has brought about a paradigm shift in how we conceive of the economic and legal realities of lending. ${ }^{33}$ From an economic perspective, the location of risk changes radically. It moves from bank balance sheets to the broader financial markets. However, as a result of this process, not only do investors hold the credit risk from, say, a pool of mortgages, but they also bear the additional risk that the issuer of the securities might fail. As a safeguard, the off-balance-sheet SPE normally organizes emergency lines of credit from prominent financial institutions, which investors depend upon in the event the issuer defaults. ${ }^{34}$ But still, such sources of emergency credit can dry up when they are needed most-this may happen, for example, if the losses on

corporate debt. See Hal S. Scott, International Finance: Transactions, Policy, and Regulation 626 (17th ed. 2010).

32. Under the Dodd-Frank Act, loan originators must retain some "skin in the game" to the tune of five percent of the unhedged risk interest in the securitization. Dodd-Frank Act $\$ 941$ (codified as amended at 15 U.S.C \$ 780-11(c)(1)(B) (2006 \& Supp. V)). The risk-retention threshold for the originator may drop below five percent if the underwriting of the assets indicates that those assets carry lower credit risk as prescribed under 15 U.S.C $\$ 78 \mathrm{o}-11$ (c)(2)(B). Id.

33. See, e.g., Adam J. Levitin \& Tara Twomey, Mortgage Servicing, 28 YALE J. ON REg. 1, 5 (2011) (providing incisive analysis of principal-agent conflict of interests affecting servicers and arguing that servicers- who are responsible for, among other functions, managing the administration of payment collection from mortgagees for investors - can be subject to incentives that favor foreclosure rather than mortgage modification); Steven L. Schwarcz, The Future of Securitization, 41 CoNN. L. Rev. 1313, 1315-16 (2009) (providing insights into both the beneficial and risky features of securitization and noting that, though securitization allows readier access to the capital markets, it can also engender moral hazard and undue reliance on models for risk analysis that may not always reflect the full spectrum of risk); Adam J. Levitin, Andrey D. Pavlov \& Susan M. Wachter, Securitization: Cause or Remedy of the Financial Crisis 3-5 (Georgetown Univ. Law Ctr., Bus., Econ. and Regulatory Policy Working Paper Series, Paper No. 1462895, 2009), available at http://papers.ssrn.com/sol3/papers.cfm? abstract_id=1462895 (arguing that, owing to the work of unregulated mortgage lenders and the high supply of mortgages deriving from their operations, investors did not fully appreciate the poor credit quality of the underlying mortgage products and, therefore, the investors did not appropriately discount the price of the securities written on these mortgages); Steven L. Schwarcz, The Universal Language of International Securitization 3-4 (Duke Univ. Sch. of Law, Global Capital Markets Center, 2002), available at $\mathrm{http}: / /$ papers.ssrn.com/sol3/papers.cfm?abstract_id=290010 (discussing the uptake and popularity of securitization internationally and the importance of recognizing securitization's core principles when undertaking cross-border securitization deals).

34. See Steven L. Schwarcz, The Alchemy of Asset Securitization, 1 STAN. J.L. Bus. \& Fin. 133, $140-41$ (1994). 
the loans underlying the securities are too deep and the emergency lender has no funds to provide this lifeline. ${ }^{35}$

The legal relationship between the borrower and its banker is irreversibly complicated by the securitization process. In a contract between a borrower and his banker-which defines the parameters of their relationship-the borrower receives funds to use for certain purposes (for example, to buy a house) and, in exchange, the bank gains myriad tools to monitor and discipline that borrower. ${ }^{36}$ Following the sale of these loans to the SPE, the original lender has little interest in properly administering a loan it no longer holds on its own books. ${ }^{37}$ Unfortunately, investors who buy the securitized loans have limited means of correcting for this tendency: investors face serious collective-action problems in coming together to renegotiate loan agreements with borrowers when, for instance, these debtors might benefit from relief on loan terms to better enable eventual repayment. ${ }^{38}$

Scholars have underscored the policy concern that, once loans are securitized, originators of loans rapidly lose motivation to act conscientiously when extending credit to ensure the credit quality of those loans. ${ }^{39}$ Banks and

35. Note that this section provided a general outline of private-label securitization. For a more detailed review of variations on the securitization model as well as the key transactional features of this process, see AsHCRAFT \& SCHUERMANN, supra note 29.

36. These tools include, for example, representations and warranties to secure information, rights to inspect secured property, rights to control how much debt a borrower may incur, rights to enforce a security, and the ability to monitor the borrower on an ongoing basis. As creditor, the bank has rights under the insolvency process to protect its interests and investments.

37. The lender might retain some residual role under its sale and purchase contract with the SPE, such as responsibility for servicing the loans.

38. See generally Adam J. Levitin, Resolving the Foreclosure Crisis: Modification of Mortgages in Bankruptcy, 2009 WIS. L. REv. 565 (noting that, although U.S. bankruptcy law has traditionally opposed restructuring loans that are secured against the main residential dwelling of a borrower, economic value can often better be preserved in a restructuring); Adam J. Levitin \& Anna Gelpern, Rewriting Frankenstein Contracts: Workout Prohibitions in Residential Mortgage-Backed Securities, 82 S. CAL. L. REv. 1075 (2009) (analyzing the pooling and servicing contracts governing securitizations and the restrictions on restructuring conventionally contained within these contracts and arguing that, in a crisis, such contractual rigidities can work as "social suicide pacts" between market participants); Levitin \& Twomey, supra note 33; Christopher L. Peterson, Foreclosure, Subprime Mortgage Lending, and the Mortgage Electronic Registration System, 78 U. CiN. L. Rev. 1359, 1361-62 (2010) (discussing the role of the Mortgage Electronic Registration System (MERS), Inc.'s system, which allows the borrower to list MERS, Inc.- the nominee agency for the actual lender-as the mortgagee on record for loan closings, ostensibly to facilitate assignment of mortgages, and further noting that over sixty million loans list MERS, Inc., as the mortgagee of record in filings).

39. Dwight Jaffee et al., Mortgage Origination and Securitization in the Financial Crisis, in Restoring Financial Stability. How To Repair a Failed Financial System 61, 68 (Viral V. Acharya \& Matthew Richardson eds., 2009) (reporting that between 2001 and 2006, subprime origination tripled from $\$ 190$ billion to $\$ 600$ billion annually while the proportion of securitization increased from $50.4 \%$ to $80.5 \%$, suggesting that subprime borrowing was ending up in a structured, securitized product); see also ASHCRAFT \& SCHUERMANN, supra note 29 (noting friction between asset manager (the agent) and investor (the principal) in that the asset manager may not invest sufficient effort on behalf of the investor); Levitin \& Twomey, supra note 33 (discussing principal-agent problem that arises when mortgage loans are securitized and the mortgage servicers' (the agents') interests become misaligned with the investors' (the principals') interests to increase the net value of the loan); Schwarcz, supra note 
others ${ }^{40}$ can fall prey to weak incentives that lead them to extend credit to unsafe borrowers ${ }^{41}$-an activity that repeats itself as banks receive fresh funds from the securitization and sale of those loans, which they then use to make more unsafe loans.

To correct these dangerous incentives postcrisis, the Dodd-Frank Act requires that lenders and issuers who securitize debt retain and share a part of the risk. $^{42}$ Still, it remains debatable whether this provides a sufficiently tight check on reckless conduct. For example, even prior to the 2008 crisis, many loan originators retained the lowest ranked tranche in their securitized portfolio to signal to the rest of the market their confidence in the deal. ${ }^{43}$ That point aside, the larger issue remains: by erasing risk from balance sheets and dispersing it across a broad constellation of investors, the securitization process incentivizes (1) lending based on suboptimal standards and (2) investment in securities based on suboptimal scrutiny of the portfolio by investors, as each investor holds only a small portion of the overall risk. If the securities benefit from emergency credit enhancement from a prominent financial firm-which is most often the case ${ }^{44}$-then investors' incentives to monitor the underlying loans grow weaker still.

The securitization process has proven problematic in another significant respect. Alongside weakened incentives to monitor the credit quality of the loan, there exists little motivation to collect accurate and complete information about a borrower at the start of the origination process. These information asymmetries are powerful. Whereas the traditional banking model motivates the lender to investigate and monitor the borrower on an ongoing basis, these incentives

33, at 1318-21 (addressing argument that securitization creates moral hazard for mortgage lenders who "d[o] not have to live with the credit consequences of their loans").

40. There may be other types of institutions involved in lending-such as mortgage companiesthat may then sell the loan to a traditional bank or investment bank. Loans may be sold among several parties before they are eventually housed in the SPE-issuing securities. See ASHCRAFT \& SCHUERMANN, supra note 29; Levitin \& Twomey, supra note 33, at 13-14.

41. Cf. Michael S. Barr et al., The Brookings institution, Discussion Paper No. 2008-14, An Opt-Out Home Mortgage System 10 (2008) (showing that borrowers do not always evaluate product choices rationally and discussing firms' practice of offering risky products to borrowers who may be psychologically primed towards an underappreciation of the risk of the mortgages).

42. See supra note 32 and accompanying text. The retention requirement must be shared between the originator and the issuer of securities. Though the loans may be sold, a portion of the risk must be retained on banks' books.

43. See Wenying Jiangli \& Matt Pritsker, The Impact of Securitization on U.S. Bank Holding Companies 3-4 (Mar. 1, 2008) (unpublished manuscript), available at http://papers.ssrn.com/sol3/ papers.cfm?abstract_id=1102284. Although firms routinely retained the toxic tranche in their issues and also faced reputational pressures to make bond payments to investors who lost money, section 941 of the Dodd-Frank Act prohibits any hedging of this five-percent-retained tranche, such that firms must keep this interest on their books and may not take out CDSs on this exposure or resecuritize it into a new issue. See supra note 32 and accompanying text.

44. Basel Comm. on Banking Supervision, Bank for Int'l Settlements, Report on Asset SecurttisaTION INCENTIVES 15-16, available at http://www.bis.org/publ/joint26.pdf. 
dissipate when loans can easily be moved off the lender's books. ${ }^{45}$ The sale of loans through various intermediaries in the securitization chain further exacerbates any initial problems that arise due to inadequate information about borrowers. Any buyer of these loans has a weak set of incentives to perform robust due diligence: the risk of these assets is invariably passed on to investors at the end of the chain. Without proper information on the credit quality of the loans, investors in the securitized instruments cannot fully gauge the extent of their risk. ${ }^{46}$ As for the investors, each of whom holds a slice of the risk of the overall portfolio rather than full exposure to that risk, there is little private motivation to incur the costs necessary to fully investigate the credit risk of the underlying loan pool. ${ }^{47}$ As a result, they may seek to free ride on existing research. This information gap has led the market to place undue reliance on the advice proffered by credit rating agencies, which are typically hired by the security issuer and can therefore be subject to capture by the interests of those who pay their fees. ${ }^{48}$ These agencies have recently fallen into highly publicized disrepute for their overly optimistic assessment of underlying mortgage pools and the skewed play of various conflicts of interest and incentives within their institutions. ${ }^{49}$

Third, encapsulating all of the above, securitization has radically dismantled the once-tight nexus between economic exposure and the legal rights that have traditionally framed this exposure. In the case of securitized home mortgages, for example, the economic risk rests with a vast cross section of investors-not necessarily the bank that originally made the loans. The legal rights and

45. Problems resulting from incomplete and incorrect paperwork on borrowers have begun to emerge in the aftermath of the 2008 financial crisis. Banks have been forced to halt foreclosures on account of faulty paperwork that failed to show the lender's interest in the loan or to properly document the assignments and registrations of property interest involved in the securitization process. The press and literature around this issue will likely grow as the full extent of these problems is revealed. See, e.g., Tami Luhby, Robo-signing: Just the Start of Bigger Problems, CNN Money (Oct. 22, 2010), http://money.cnn.com/2010/10/22/real_estate/foreclosure_paperwork_problems/index.htm; see also Adam J. Levitin \& Susan M. Wachter, Information Failure and the U.S. Mortgage Crisis, in THE american Mortgage System: Crisis and Reform 243, 256-57 (Susan M. Wachter \& Marvin M. Smith eds., 2012); Peterson, supra note 38.

46. See Dodd-Frank Act $\S 941$ (codified as amended at 15 U.S.C $\S 780-11(c)(1)(B)$ (2006 \& Supp. V)).

47. Levitin \& Wachter, supra note 45 , at $256-57$.

48. Id. at 257-59 ("Because structured product issuers were looking to manufacture as much investment-grade paper as possible, the rating agencies were under pressure to give investment grade ratings, even if it meant making off-model adjustments."); see also Yair Listokin \& Benjamin Taibleson, If You Misrate, Then You Lose: Improving Credit Rating Accuracy Through Incentive Compensation, 27 YALE J. ON REG. 91 (2010) (noting the poor performance of rating agencies on account of the issuer-pays model whereby issuers of securities pay the rating agencies for giving ratings on the issue).

49. See, e.g., Listokin \& Taibleson, supra note 48 . It should also be noted that, while Title IX of the Dodd-Frank Act subjects credit-rating agencies to more comprehensive oversight with new rules on conflicts of interest, the Act does not change the issuer-pays model for credit rating. E.g., John Patrick Hunt, Credit Rating Agencies and the "Worldwide Credit Crisis": The Limits of Reputation, the Insufficiency of Reform, and a Proposal for Improvement, 2009 ColuM. Bus. L. Rev. 109 (arguing that reputational capital of rating agencies does not guarantee high-quality ratings). 
obligations (for example, the benefit of representations and warranties from the debtor as well as the rights to take and enforce a security) attaching to those risks, however, are divided among the lender, servicer, issuer of securities, and the investors. Because of the collective-action issues noted above and the weakened incentives of the lender to exercise its claims, the significance and practical bite that these legal rights once carried has diminished considerably.

\section{B. AN OVERVIEW OF CREDIT DERIVATIVES}

A derivative is a financial contract whose value is "derived" by reference to an underlying asset or benchmark. This means that a derivative cannot exist in the absence of that which it references. The asset classes or benchmarks that a derivative can reference are vast. ${ }^{50}$ They include categories such as equities, fixed-income securities, commodities, as well as-more quirkily— "assets" such as the weather or measures like inflation..$^{51} \mathrm{~A}$ credit derivative is a contract whose value is attached to any change in the credit quality of an issuer of securities, the securities themselves, or another debt instrument. ${ }^{52}$ This Article defines a credit derivative as a contract whose value is determined by changes in the credit risk of an underlying asset (such as a security) or entity (such as an issuer or borrower).$^{53}$ In other words, a credit derivative can buy or sell the risk that a certain entity or security will suffer a loss. Risk may arise where the securities fail to pay out for a specified reason or where the issuer suffers a catastrophic default, and the investor no longer receives the returns from its investment that it expected contractually. Credit derivatives can protect investors from such losses. Sellers of credit protection gain exposure to underlying issuers or securities without going to the trouble of buying these assets themselves.

Key types of credit derivatives include credit-default swaps (CDSs), creditlinked notes (CLNs), and total-return swaps (TRSs). The CDS dominates the market and has become infamous in the wake of the crisis. Its key features are described below.

50. The derivatives market has grown exponentially since the 1970 s. Recent estimates by the Bank for International Settlements indicate that, for the year ending in December 2011, the notional amounts outstanding on currency derivatives, interest-rate derivatives, and credit-default swaps were approximately $\$ 63$ trillion, $\$ 504$ trillion, and $\$ 29$ trillion, respectively. BANK FOR INT'L SETTLEMENTS, SEMIANNUAL OTC Derivatives Statistics AT END-December 2011 tbls.19, 20A (Sept. 2012), available at http://www.bis.org/statistics/derstats.htm. The amount outstanding on credit-default swaps was down from $\$ 32.7$ trillion in 2009. Id.

51. René M. Stulz, Demystifying Financial Derivatives, Milken InST. Rev., 3d Quarter 2005, at $20-24$.

52. Product Descriptions and Frequently Asked Questions, InT'L SwaPs \& DerIVATIVes Ass'N, http://www.isda.org/educat/faqs.html\#25 (last visited Oct. 14, 2012).

53. For further discussion on other examples of credit derivatives, see J.P. MORGAN, THE J.P. MORGAN Guide to Credit Derivatives (1999). 


\section{Credit-Default Swaps}

CDSs protect against the risk of losses if an underlying debt or obligation defaults. Thus, a CDS protection seller agrees to protect a buyer if there is a loss on an underlying asset or entity in exchange for a regular premium ${ }^{54}$ paid by the buyer for the term of the contract. This protection premium fluctuates depending on how risky the underlying reference asset becomes: if the risk of loss on the reference asset increases, then the premium also increases. The protection provider makes collateral available to the buyer to demonstrate the provider's creditworthiness. Again, the amount of collateral demanded may change depending on the likelihood of the protection provider having to pay out. The greater the chance of the provider paying out, the higher the amount of collateral it must provide. ${ }^{55}$

The market relies on CDS contracts both for hedging and for speculative purposes. Indeed, Professors Frank Partnoy and David Skeel have remarked that CDSs proved critical during the WorldCom and Enron scandals. ${ }^{56}$ In each case, creditor banks of both WorldCom and Enron outmaneuvered heavy losses of several billion dollars by virtue of the CDS protection that they had taken out beforehand.$^{57}$ In addition to hedging, CDSs permit speculative trading. Because CDS contract parties do not actually need to buy an underlying reference asset, they are free to buy or sell protection on assets that they may not actually own. ${ }^{58}$ The act of buying or selling protection entails taking a position on the future fortunes of the underlying asset—and may, therefore, entail pure speculation. ${ }^{59}$

\section{Why Use Credit Derivatives?}

Credit derivatives present a number of advantages for the market. ${ }^{60}$ First, CDSs allow parties to manage their risk in a flexible manner. Those who buy risks are-or hold themselves out to be-in a better position to take risks, and these trades for risk represent calculated investment decisions. The ability to hedge risks works to reduce capital costs: parties who hedge their risks on a portfolio of loans can set aside less capital to cover the risk of the loans than they would otherwise need without the credit derivative. This means, for example, that a bank, having shifted some risk off its books through a derivative, has extra liquidity to make loans into the real economy. ${ }^{61}$

54. This periodic fee is usually expressed as a percentage of the notional value of the asset.

55. See ScotT, supra note 31 , at 852 .

56. Partnoy \& Skeel, supra note 21 , at $1021 \mathrm{nn} .1-2$.

57. Id. at $1021 \mathrm{n} .2$.

58. See ScotT, supra note 31 , at 852.

59 . The ability to use derivatives speculatively has been widely criticized by scholars as promoting excessive risk taking and overcomplexity. However, the ability to transact speculatively has also been justified as allowing for a more liquid market in CDSs. For a discussion of these issues, see Lynn Stout, Regulate OTC Derivatives by Deregulating Them, REGULATION, Fall 2009, at 30.

60. See Partnoy \& Skeel, supra note 21, at 1022-29.

61. See Bank For InT'L Settlements, QuantTtative ImPact Study III: Technical Standards TII 103$05,154-57(2002)$. 
Second, credit derivatives can lower entry and participation costs where parties can better manage their risks. The ability to hedge and speculate on risk allows key institutional investors (such as pension funds or mutual funds) to enter into investments that are less constrained by the levels of risk that they are allowed legally to assume.

Third, derivatives facilitate better price discovery. These instruments serve to extract information with respect to the risk of an underlying asset and how much investors should be paying for it. Following the crisis, commentators have lamented the lack of transparency in the OTC-derivatives market. ${ }^{62}$ Yet, despite being off exchange, information on credit derivatives did exist well before the crisis-clearinghouses provided this information while market indices, such as the $\mathrm{ABX}$ indices, also offered information about the OTCderivatives market. In the run-up to the crisis, these indices presciently yielded initial inklings ${ }^{63}$ that all might not be well with the credit market. ${ }^{64}$

Fourth, active markets, boasting many classes of participants, can boost economic growth. Professors Duffie and $\mathrm{Hu}$ have noted the economic benefits provided by deep OTC-derivative markets in the past. ${ }^{65}$ They argue that these have enhanced not only company bottom lines through successful risk and speculation strategies, but also employment numbers, particularly in the financialservices industry. ${ }^{66}$ Financial hubs such as London, New York, and Chicago experience higher standards of living through revenues and taxes generated from their competitive pull as global investment centers. ${ }^{67}$

Notwithstanding the above, postcrisis fallout has revealed some of the darker aspects of credit derivatives. In the aftermath of the AIG collapse, reports revealed that firms bought credit derivatives in order to take on large exposures (such as investments in mortgage-backed securities) with the knowledge that these exposures could ultimately be hedged. ${ }^{68}$ Credit-protection providers could afford to assume such exposures given that they could sell it to someone else

62. G-20 PItTSBURGH Summit, supra note 2, II 13; see also CCMR RePORT, supra note 19, at ES-7 to ES-8.

63. See discussion infra section III.A.

64. Viral V. Acharya et al., Derivatives: The Ultimate Financial Innovation, in RESTORING FinANCIAL Stabiltry: How To Repair a Falled System, supra note 39, at 233, 234. A detailed analysis of the way in which $\mathrm{ABX}$ indices revealed CDS prices can be found in Gary Gorton, The Subprime Panic 21-23 (Yale Int'l Ctr. for Fin., Working Paper No. 08-25, 2008), available at http://ssrn.com/abstract= 1276047.

65. See Darrell Duffie \& Henry T.C. Hu, Competing for a Share of Global Derivatives Markets: Trends and Policy Choices for the United States (Univ. of Tex. Law, Law \& Econ. Research Paper No. 145, 2008), available at http://papers.ssrn.com/sol3/papers.cfm?abstract_id=1140869.

66. Id. at 7-8.

67. See id. at 8 .

68. See, e.g., UBS, Shareholder Report on UBS's Write-Downs 12-14 (2008), available at http://www.ubs.com/1/ShowMedia/investors/agm?contentId $=140333$ name $=080418$ ShareholderReport. pdf; Henry Hu, 'Empty Creditors' and the Crisis: How Goldman's \$7 Billion Was 'Not Material,' Wall St. J., Apr. 10, 2009, http://online.wsj.com/article/SB123933166470307811.html (defining the empty creditor as one who has contractual control rights "but, by simultaneously holding credit default swaps, little or no economic exposure if the debt goes bad"). 
deeper in the derivative market. ${ }^{69}$ Professor Margaret Blair argues that credit derivatives can thus amplify levels of leverage in the market to unsafe and unmanageable levels-until these structures inevitably and catastrophically unravel, as seen in the crisis. ${ }^{70}$

These findings illuminate the intricate legal and economic workings of credit derivatives. First, securitization fractures the traditional nexus existing between the economic risk of a loan and the legal relationships that frame and control that risk. This fracture holds heavy regulatory implications: creditors' incentives to monitor their borrowers weaken, creditors' underwriting standards relax, and investors' collective-action problems prevent them from asserting corrective disciplinary measures to control these problems. Critically, the securitization process places economic risk in the hands of those who do not hold the full spectrum of legal tools to contain the risk, such as investors, and-converselyplaces those legal tools with those who carry limited economic exposure, such as lenders and originators of securities. ${ }^{71}$

The credit derivative amplifies this regulatory disconnect. In buying credit protection on its securitized bonds, the investor sells a sliver of the economic risk within the pool of home loans to another entity in the financial markets. Whatever weak legal mechanisms the investor possessed (such as the ability to demand information from the securities issuer or to engage a trustee for the issue) are further weakened when this risk is subject to sale using a CDS. The credit-protection seller only ends up with an indirect route to protect its exposure, as exercised through its contract with the credit-protection buyer. If this credit-protection seller then sells this risk further, the limited bundle of legal rights it had becomes thinner still for the next buyer.

Second, securitization enables the selling and pooling of more than just the straight risk of the underlying batch of loans. In addition to the credit risk of the loans materializing and defaulting, the issuer can also fail. Moreover, any credit enhancement or insurance to keep the securitized issue solvent might not come through. The entry of the credit derivative exacerbates this multiplication of risk sources even further. For instance, a credit-protection buyer, in offloading its risk, faces the possibility that its counter party might go bust or the market might become volatile, causing the value of the seller's collateral to fall quickly and precipitously-leading to calls for more collateral to be posted. ${ }^{72}$ The

69. See Partnoy \& Skeel, supra note 21, at 1040 (discussing systemic concerns that CDSs raise).

70. Margaret M. Blair, Financial Innovation, Leverage, Bubbles and the Distribution of Income, 30 REv. Banking \& Fin. L. 225 (2011).

71. See supra notes $36-41$ and accompanying text.

72. The latter possible source of risk-the demand for additional collateral-was borne out in the lead up to the collapse of Bear Stearns and AIG. See, e.g., Am. Int'l Grp., Inc., Annual Report (Form 10-K) 20-22 (Mar. 16, 2006) (documenting the downgrade of AIG from AAA to AA that then required the insurer to start posting collateral on its swaps in 2005); Alistair Barr, Bear Stearns' Credit Hedge Funds Almost Wiped out, MARKETWATCH (July 18, 2007), http://www.marketwatch.com/story/bear-stearnscredit-hedge-funds-almost-wiped-out; Brady Dennis \& Robert O'Harrow Jr., A Crack in the System, WASH. Post, Dec. 30, 2008, at A01; Gretchen Morgenson, Behind Insurer's Crisis, Blind Eye to a Web 
credit-protection seller also faces multiplied risk: a buyer of credit protection might fail, which would lead to a loss of revenue for the seller, who is no longer collecting regular premium payments. This can be serious because, if the revenue stream is essential for the credit-protection seller to fund her own obligations in the market, she will be required to search for other sources of revenue to compensate for the losses. ${ }^{73}$

CDSs also render more powerful the incentive risks outlined throughout this Article. CDS protection sellers have little motivation to monitor their CDS protection buyers where the sellers can pass this risk on to yet another party. As the number of such transactions increase, so do the monitoring costs that any one CDS protection seller must internalize. This multiplying chain incrementally reduces the likelihood of CDS protection sellers exercising due diligence of CDS exposures. The usual private-order monitoring mechanisms in the contract between the CDS protection buyer and seller thus become mostly theoretical. Shareholders and regulators may also be poor policemen. Exposures taken on by protection sellers may only be revealed in annual balance sheet audits, leaving regulators and the market poorly informed of the ongoing state of risk affecting an institution. ${ }^{74}$ More nefariously, as posited by Professor Richard Squire in the case of AIG for example, shareholders and managers come to regard the risk as worth taking in the interests of amplifying company value through high degrees of leverage. ${ }^{75}$ These incentive risks gain systemic proportions where the credit risk that is being traded is highly correlated. In other words, where parties are taking risks on similar types of asset classes or assets with value that is likely to be closely aligned (such as mortgagebacked securities, securities referenced to credit cards, or other consumer debt), then the impact of losses will be felt deeply, broadly, and simultaneously.

of Risk, N.Y. Times, Sept. 27, 2008, http://www.nytimes.com/2008/09/28/business/28melt.html; Robert O'Harrow Jr. \& Brady Dennis, Downgrades and Downfall, WASH. Post, Dec. 31, 2008, at Al; Mary Williams Walsh, A.I.G. Secures \$150 Billion Assistance Package, N.Y. Times, Nov. 10, 2008, http:// www.nytimes.com/2008/11/11/business/1 linsure.html.

73. In so-called "CDO-squared" transactions-or synthetic CDOs-the revenue stream from a set of CDS-protection buyers can be used as the reference asset pool for a securitization. This means that, where a large CDS-protection seller has securitized its portfolio of CDSs and the revenue stream from the CDS pool dries up, the seller might face calls to provide liquidity through credit-enhancement arrangements or reputational pressures in this market may force the seller to cover the losses itself

74. The AIG 2005 Annual Report, for example, did not mention the notional value of the CDSs that it had insured. See Am. Int'l Grp., Inc., supra note 72.

75. See Richard Squire, Shareholder Opportunism in a World of Risky Debt, 123 HaRv. L. Rev. 1151, 1182-91 (2010); see also Richard Squire, Strategic Liability in the Corporate Group, 78 U. CHI. L. Rev. 605 (2011). Professor Squire argues that shareholders exhibit opportunistic correlation-seeking behavior. See Squire, Shareholder Opportunism, supra, at 1151; Squire, Strategic Liability, supra, at 622-39. Within a corporate group, companies benefit from giving each other cross guarantees, even when the insolvency risk of group companies is highly correlated. Squire, Strategic Liability, supra, at 629-36. This correlation is advantageous because it lowers the costs to shareholders of the group companies to obtain financing. Id. The ultimate costs are shifted to the creditors because shareholders know they will be wiped out in any event and will not be able to make good on their intragroup guarantees. Id. 
Third, the derivative market compounds existing information asymmetries. In securitization, lenders and issuers have little motivation to collect and disclose full information on borrowers. ${ }^{76}$ Similarly, for credit derivatives, CDSprotection sellers are unlikely to bargain for information on the underlying portfolio of securities-let alone the risk underlying those securities such as home mortgages or other reference assets-when this risk can be passed on. Information costs are amplified because incentive risks are hard to measure and internalize. Information asymmetries are built into the OTC market. Although credit derivatives have often proven useful as an information source, these data are intrinsically complex in nature and also sufficiently new to the market that they do not benefit from a meaningful history against which to understand them. Unsurprisingly, the market has routinely struggled fully to understand and internalize the implications of credit-derivatives trading. This complexity extracts an especially high cost when parties are unable to gauge where risky exposures come to rest. ${ }^{77}$

\section{The Law and EConomics of Clearinghouses}

Since its establishment in the U.S. futures markets in 1883, the clearinghouse has become a critical fixture of the financial system. ${ }^{78}$ It represents an essential private ordering of actors to collectively achieve public-policy ends. ${ }^{79}$ Clearinghouses process and settle trades in various types of financial productsincluding equities, bonds, and certain derivatives-in the United States and abroad. ${ }^{80}$ They operate in nearly all major, developed markets and deal in myriad varieties of securities. ${ }^{81}$ The New York Stock Exchange, ${ }^{82}$ NASDAQ,${ }^{83}$

76. See supra notes $39-41$ and accompanying text.

77. Morgenson, supra note 72 ; Walsh, supra note 72.

78. For a historical perspective, see Franklin R. Edwards, The Clearing Association in Futures Markets: Guarantor and Regulator, in The Industrial Organization of Futures Markets 225, 225 (Ronald W. Anderson ed., 1984); Randall S. Kroszner, Can the Financial Markets Privately Regulate Risk?: The Development of Derivatives Clearinghouses and Recent Over-the-Counter Innovations, 31 J. Money, Credit \& BANking 596, 598-604 (1999); and James T. Moser, Contracting Innovations and the Evolution of Clearing and Settlement Methods at Futures Exchanges (Fed. Reserve Bank of Chi., Working Paper No. WP-98-26, 1998).

79. $C f$. Kroszner, supra note 78 (describing clearinghouses in the context of the futures markets in the United States and noting that clearinghouses have a long and extensive history of use in the area of payment systems). See generally Moser, supra note 78 (studying the establishment of the clearinghouse and its impact on futures contracts).

80. See MCPartLand, supra note 3, at 1. For an international perspective, see Comm. ON PAYMENT \& Settlement Sys., Bank for Int'l Settlements, Payment, Clearing and Settlement Systems in the CPSS COUNTRIES (2011), http://www.bis.org/publ/cpss97.htm (providing a survey of clearing and settlement systems in twenty-four member countries of the Committee on Payment and Settlement Systems of the Bank for International Settlements).

81. See, e.g., National Securities Clearing Corporation, DTCC, http://www.dtcc.com/about/subs/ nscc.php (last visited Oct. 15, 2012) (stating that the DTCC subsidiary, the National Securities and Clearing Corporation, offers clearing services for a variety of security types, including equity, municipal debt, American depository receipts, and exchange-traded funds). 
the Chicago Mercantile Exchange ${ }^{84}$ the London Stock Exchange, ${ }^{85}$ and the Singapore Stock Exchange ${ }^{86}$ (to name a few) all rely on clearinghouses to finalize trades. The dollar value of these transactions is extraordinary. Reiterating its centrality to the market, the U.S.-based Depository Trust and Clearing Corporation (DTCC) (acting through subsidiaries) reported settling over one quadrillion dollars in trades in 2010. ${ }^{87}$

The clearinghouse's basic process can be illustrated, briefly, as follows:

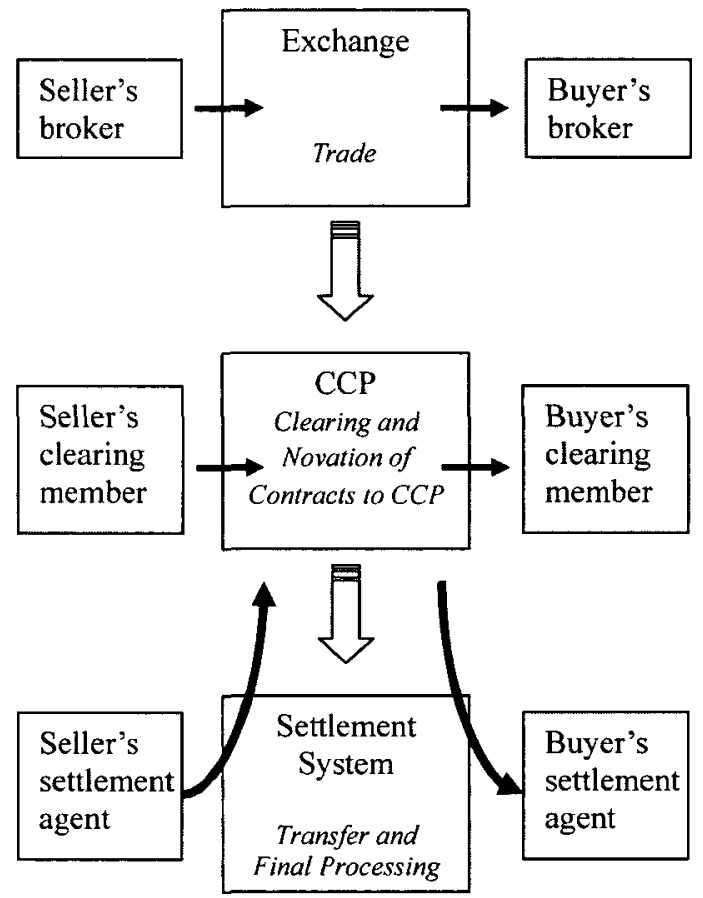

Figure 1

82. NYSE Arca Equities Clearing, NYSE EuRONEXT, http://usequities.nyx.com/markets/nyse-arcaequities/clearing (last visited Oct. 15, 2012) (noting its use of DTCC subsidiary, National Securities Clearing Corporation).

83. Clearing \& Settlement, NASDAQ OMX, http://www.nasdaqomx.com/2011/whatwedo/market technology/clearingandsettlement/ (last visited Jan. 30, 2012).

84. Clearing, CME Group, http://www.cmegroup.com/clearing/ (last visited Oct. 15, 2012).

85. London Stock Exchange, LCH.CLEARNET, http://www.lchclearnet.com/cash_equities/lse/ (last visited Oct. 15, 2012) (briefly describing LCH.Clearnet's clearing arrangements for the London Stock Exchange).

86. Securities Clearing, SINGAPORE EXCHANGE LTD., http://www.sgx.com/wps/portal/sgxweb/home/ clearing/securities/securities_clearing (last visited Oct. 15, 2012).

87. See supra note 4 and accompanying text (citing DTCC reports of $\$ 1.669$ quadrillion in trades in 2010). As discussed supra, the DTCC provides clearing services for some of the largest public markets in the United States, such as the New York Stock Exchange. See, e.g., NYSE Arca Equities Clearing, supra note 82 . 
This section provides an overview of the organizational and operational features of clearinghouses and then analyzes the incentive structures and behavioral dynamics that animate their function. Specifically, this section describes: (1) the core functions of the clearinghouse; (2) the essential features of clearinghouse governance; and (3) the incentive risks that result from clearinghouse members using the clearinghouse to carry out risky and privately profitable trades.

\section{A. CORE FUNCTIONS}

The clearinghouse provides certainty and safety to financial-market trading. Historically, it began as something of a regulatory afterthought, following the establishment of the securities exchange. ${ }^{88}$ Exchanges provide a marketplace for buying and selling various types of securities, such as shares, bonds, or commodity derivatives (such as wheat futures). ${ }^{89}$ These markets bring buyers and sellers together, provide transparent pricing structures, and mandate that contracts used on the exchange be fully standardized. ${ }^{90}$ Pro-forma contracts are fungible in that they are interchangeable and easily transferred between parties. If trades exhibit highly tailored features (for example, a reference to a rare brand of copper), they cannot easily trade on an exchange. Exchanges facilitate the creation of economies of scale for trading securities, generating a liquid ${ }^{91}$ and dynamic capital market for a large variety of security types. ${ }^{92}$

This marketplace created the worry that parties on the other side of the trade might not be good for their bargain to buy or sell a security. ${ }^{93}$ Though members of the exchange likely knew each other, there was little guarantee that parties, having made a bad bet, would not renege on their commitment. If several parties defaulted on their promise to trade, or if one party's default led to a chain of such failures, then market paralysis could result. The clearinghouse originated as a response to these concerns. Its instrumental features reflect an attempt to remedy these shortcomings and minimize trading risks. While schol-

88. See Pirrong, supra note 9.

89. See Andreas M. Fleckner, Stock Exchanges at the Crossroads, 74 Fordham L. Rev. 2541, 2546-47 (2006) (noting that exchanges bring together market participants and mediate information asymmetries between market actors).

90. Id.; see also, e.g., Our Contracts, LondOn METAL EXCHANGE, http://www.lme.com/what_contracts. asp (providing examples of standard contracts for derivative contracts traded on an exchange for use by members of the exchange).

91. See Fleckner, supra note 89, at 2546, 2577-79 (discussing ways in which clearinghouses provide liquidity and create economies of scale).

92. See Lowell D. Hill, Grain Grades and Standards: Historical Issues Shaping the Future (1990); Henry Crosby Emery, Speculation on the Stock and Produce Exchanges of the United States, in 7 Studies in History Economics and Public Law 283 (Faculty of Political Sci. of Columbia Univ. eds., 1896); Kroszner, supra note 78; Moser, supra note 78; Randall S. Kroszner, Private Versus Public Regulatory Structures in International Financial Markets: An Analysis of Derivative Products Companies (U. of Chi. Booth Sch. of Bus., Working Paper, 1999).

93. Craig Pirrong, The Economics of Central Clearing: Theory and Practice 5-6 (Int'l Swaps \& Derivatives Ass'n, Discussion Paper Series No. 1, 2011), available at http://www2.isda.org/functionalareas/research/discussion-papers/. 
ars have traditionally devoted considerable attention to the role of exchanges, ${ }^{94}$ the clearinghouse has attracted little attention, ${ }^{95}$ regarded, somewhat unfairly, as performing a "nuts and bolts" function for the work undertaken by exchanges.

Clearinghouses are designed to achieve multiple purposes. First, they ensure that trades executed on an exchange ${ }^{96}$ are settled. This means that, for each transaction, the clearinghouse transfers securities from the selling party to the buying party and passes cash from the buying party to the selling party. Second, clearinghouses act as a buffer against market paralysis by allowing losses to be shared among clearinghouse members and absorbed before they seep into the financial system. Finally, clearinghouses implement a governance structure for sharing losses that vets those using it. This means making sure that member institutions are solvent and able to cover the bets that they make, principally by providing collateral to the clearinghouse that can be easily sold to meet costs and make up for any losses. ${ }^{97}$

The clearinghouse reduces counterparty default risk by serving as the contract party for each trade that it processes. The clearinghouse achieves this by legally novating contracts to itself, such that it becomes liable for ensuring that

94. See Chris Brummer, Post-American Securities Regulation, 98 CALIF. L. Rev. 327 (2010) (providing insights into the increasing competition between national markets and regulators that undermines the likelihood of adopting common rules for securities markets globally); Stephen J. Choi \& Andrew T. Guzman, Portable Reciprocity: Rethinking the International Reach of Securities Regulation, 71 S. CAL. L. REv. 903, 916 (1998) (arguing for issuers' "choice" as to which securities-law regime they wish to transact under); John C. Coffee, Jr., The Rise of Dispersed Ownership: The Roles of Law and the State in the Separation of Ownership and Control, 111 YALE L.J. 1 (2001) (noting the role of the common law as able to facilitate decentralized private self-regulation of markets, exemplified by the NYSE); Fleckner, supra note 89, at 2575-79 (discussing the regulatory implications of stock exchanges becoming publicly traded companies); Jonathan Macey \& Hideki Kanda, The Stock Exchange as a Firm: The Emergence of Close Substitutes for the New York and Tokyo Stock Exchanges, 75 CORNELL L. REv. 1007 (1990) (discussing the highly competitive pressures facing exchanges, dispelling the notions that these organizations function as monopolies, and arguing that the economic function of exchanges must be analyzed within the prism of an increasingly competitive marketplace for listing services); Paul G. Mahoney, The Exchange as Regulator, 83 VA. L. REv. 1453, 1455 (1997) (proposing that increased competition between exchanges-rather than between national regulators-may be beneficial for capital mobility); Roberta Romano, Empowering Investors: A Market Approach to Securities Regulation, 107 YALE L.J. 2359, 2361-62 (1998) (arguing for states to compete for investors by competitively offering securities-law regimes). For an alternative perspective, see Merritt B. Fox, Retaining Mandatory Securities Disclosure: Why Issuer Choice Is Not Investor Empowerment, 85 VA. L. REV. 1335 (1999) (advocating against issuer choice, owing to the likelihood of a race to the bottom in relation to investor protection).

95. Craig Pirrong argues that industry members were reluctant to come together to form the clearinghouses but eventually did so through government pressure. Pirrong, supra note 9. Pirrong discusses the Tin Crisis from 1985 to 1986 when the London Metal Exchange suffered a catastrophic failure as a result of prices in tin falling suddenly. Id. Following that crisis, the exchange had to close its doors until it could steady itself to resume operations. Id. In 1985 to 1986, the LME operated without a CCP, but it eventually transferred to using a CCP after it was threatened with the loss of its license by U.K. regulatory authorities. See id. It should be noted that the dynamics of the clearinghouse have been studied by finance scholars. See Kroszner, supra note 78; Moser, supra note 78; Pirrong, supra note 1.

96. Clearinghouses can also clear trades that are executed OTC.

97. Pirrong, supra note 93, at 6-8. 
trades complete. ${ }^{98}$ Thus, if parties use a clearinghouse, they do not need to assume credit risk on one another. Instead, they take risk only on the clearinghouse as the CCP. In contrast, where parties assume bilateral risks, they may take on too much risk, becoming dangerously vulnerable in the event one or other party fails. Take the case of AIG, for example, which ended up selling vast amounts of credit protection across Wall Street in the largely OTC-creditderivative market. As is now well-known, AIG had to be saved by a $\$ 180$ billion federal bailout because of key Wall Street players who depended on the protection AIG sold in the CDS market. ${ }^{99}$

Although the CCP reduces counterparty risk, it does not eliminate this risk altogether because the CCP itself might fail. This can happen if the CCP has to perform on contracts and does not have the resources to meet the costs of completing its obligations. ${ }^{100}$ To prevent this eventuality from taking place, a second key function of the clearinghouse requires that losses be shared among its members. ${ }^{101}$ Parties that suffer losses on their contract pay first and, where they fall short, losses are covered by the remaining solvent members. Clearinghouses enable the mutualization of losses. ${ }^{102}$ As further protection, the clearinghouse demands that members provide collateral to reflect the changing risk on the contract. ${ }^{103}$ Members can thereby internalize the costs of failure to reduce externalities reverberating into the financial system as a whole.

The clearinghouse generates efficiencies for the market. First, parties face reduced default risks by entering into a contract with the CCP. When contracting with the CCP, a party assumes much lower costs of due diligence because a party need only assure the creditworthiness of the CCP, rather than individual counterparties in the market. This ability to bypass idiosyncratic risk allows more firms to enter the capital markets. Because parties buy and sell standardform products, they do not have to expend private resources to study complex risks. ${ }^{104}$ Players assuming more standard-form obligations should generally face

98. Id. at 6-7.

99. See, e.g., Binyamin Appelbaum, Report Says New York Fed Didn't Cut Deals on AlG, N.Y. TimEs, Oct. 31, 2011, http://www.nytimes.com/2011/11/01/business/gao-says-new-york-fed-failed-topush-aig-concessions.html.

100. See Thorsten V. Koeppl \& Cyril Monnet, The Emergence and Future of Central Counterparties 2 (Research Dep't, Fed. Reserve Bank of Phila., Working Paper No. 10-30, 2010).

101. See Robert E. Litan, The Derivatives Dealers' Club and Derivatives Markets Reform: A Guide for Policy Makers, Citizens and Other Interested Parties 6, THE BROOKINGs InstTTUTE (2010), http:// www.brookings.edu/papers/2010/0407_derivatives_litan.aspx (enumerating measures clearinghouses employ to protect themselves from losses).

102. Id.

103. See, e.g., Stephen G. Cecchetti, Jacob Gyntelberg \& Marc Hollanders, Central Counterparties for Over-the-Counter Derivatives, BIS Q. REv., Sept. 2009, at 45, 47-48.

104. See Thorsten V. Koeppl, Time for Stability in Derivatives Markets: A New Look at Central Counterparty Clearing for Securities Markets 1-5 (C.D. Howe Institute, Commentary No. 329, 2011) (discussing ways in which clearinghouses mitigate risk). Standardization of formerly OTC derivative contracts is a key feature of new postcrisis reforms. Commitment Letter, OTC Derivatives Supervisors Grp., Summary of OTC Derivatives Commitments (March 2011), http://www.newyorkfed.org/ newsevents/news/markets/2011/SCL0331a.pdf. 
lower capital costs, because they do not have to make provisions (for example, through extra collateral) for tailored risks that may be hard to resell down the line. ${ }^{105}$

Second, clearinghouses provide information to the market by disseminating information to their membership. While exchanges provide a well-known means of publishing information on trading activity, ${ }^{106}$ the clearinghouse is also valuable in this regard. Clearinghouses furnish intelligence on aggregate exposures to certain industries, sectors, or parties in the market, as well as information on the net or gross vulnerability of each party. ${ }^{107}$ Such insights provide informational gains for firms as well as for regulators. Fulsome data permit market risks to be internalized by private parties in a timely manner, which then allows those parties to react by, for example, adjusting the pricing of securities. From the perspective of regulators, advantages accrue where authorities use market information to promptly police bad behavior. ${ }^{108}$

Third, the mutualization of losses fosters firm-level self-restraint: players insure risks for each other. ${ }^{109}$ Mutualization instills shared norms that punish players for assuming too much risk. The clearinghouse's risk-mitigation measures are designed to stop trades with a misbehaving party by threatening expulsion of members if they fail to abide by the rules. ${ }^{10}$ In theory, continuous trade monitoring and reporting in real time should catch signs of risky behavior early and prevent risks from materializing for the clearinghouse. Because members have their own money on the line, soft pressures to discipline other reckless members should be particularly effective. For the financial system, the mutualization model works to contain catastrophic losses within the clearinghouse. In the OTC market, parties acting bilaterally make their own decisions

105. See Koeppl, supra note 104, at 5-6 (highlighting that a CCP "offering netting could also reduce collateral costs for market participants").

106. See Fleckner, supra note 89 , at 2546-57. For example, the DTCC reports equity settlement data using its Trade Capture and Reporting Service. This service validates trade details, as provided by exchanges and broker dealers, and reports them to DTCC members throughout the trading day. For an overview, see Trade Capture and Reporting Service, DTCC, http://www.dtcc.com/products/cs/ equities_clearance/tcr_otcc.php (last visited Oct. 15, 2012).

107. See, e.g., DDR Swap Data Repository, DTCC, http://www.dtcc.com/products/derivserv/suite/ us_swap_data_repository.php (last visited Oct. 15, 2012); Market Data, CME GROUP, http://www. cmegroup.com/market-data/ (last visited Oct. 15, 2012).

108. Provisions in the Dodd-Frank Act that mandate trade reporting of derivative transactions were designed, in part, so that regulators can identify accumulations of risk as well as manipulative trading behavior. Dodd-Frank Act $\S \S 763,766$ (codified as amended at 15 U.S.C. $\S \S 78 c-3-78 c-5,78 j-2$, 78m-1 (2006 \& Supp. V)).

109. See, e.g., Saule T. Omarova, Wall Street as Community of Fate: Toward Financial Industry Self-Regulation, 159 U. PA. L. Rev. 411 (2011) (arguing that forcing more risky firms to fully internalize the costs of their risk taking through an insurance fund or removal of state support, for example, should force better self-regulation by the actors and reduce systemic risk); Steven L. Schwarcz, Response, Financial Industry Self-Regulation: Aspiration and Reality, 159 U. PA. L. Rev. PENNumbra 293, 297-98 (2011) (agreeing with Professor Omarova that distorted incentives of private actors can lead to systemic risks and arguing for greater internalization of costs by market participants).

110. See Thorsten V. Köppl, Risk Sharing Through Financial Markets with Endogenous Enforcement of Trades 16 (Eur. Cent. Bank, Working Paper Series No. 319, 2004). 
with respect to the amount, timing, and quality of collateral to support their risks and the manner in which parties divide losses. ${ }^{111}$ Left to their own devices, parties may devise inadequate arrangements. Where losses are left to be allocated by an unpredictable and lengthy bankruptcy process, the losses can escalate idiosyncratically. ${ }^{12}$ Under mutualization, the standard wisdom is that market participants should be responsible for the costs of their own risk taking within an organized legal and institutional framework. Member institutions bear the full cost of losses, rather than shifting these to the taxpayer or to creditors. ${ }^{113}$

These features came to the fore during the 2008 financial crisis. Clearinghouses generally fared well in managing the crisis's defining event-the bankruptcy of Lehman Brothers. For example, LCH.Clearnet, a prominent clearinghouse, succeeded in winding down, closing out, or transferring a ninetrillion-dollar portfolio of interest-rate swaps involving Lehman Brothers. ${ }^{114}$ Indeed, LCH.Clearnet did not even dip into the default fund. ${ }^{115}$ It showcased the high utility of the clearinghouse as a safeguard against systemic catastrophe.

Still, as clearinghouses move to clear complex derivatives, caution must prevail. Importantly, in the past, clearinghouses have failed or teetered dangerously close to the precipice of failing during times of systemic crisis. In the market collapse that followed the stock market crash of October 1987, for example, the Chicago Mercantile Exchange and the Options Clearing Corporation were literally seconds from failure and threatened to close their doors because of insufficient capital buffers to continue operations. ${ }^{16}$ In 2008 , the LCH.Clearnet default process entailed the failure of only one-albeit, impor-

111. See Pirrong, supra note 93 , at 7-8.

112. See Viral Acharya \& Alberto Bisin, Counterparty Risk Externality: Centralized Versus Over-theCounter Markets 3-6 (Nat'l Bur. of Econ. Research, Working Paper No. 17000, 2010), available at http://papers.ssm.com/sol3/papers.cfm?abstract_id=1573355.

113. In theory, creditors should face limited losses as the CCP is charged with completing trades qua CCP.

114. See Julia Lees Allen, Note, Derivatives Clearinghouses and Systemic Risk: A Bankruptcy and Dodd-Frank Analysis, 64 StAN. L. REv. 1079, 1089-90 (discussing the auction process used by LCH.Clearnet to manage the Lehman Brothers's interest-rate swap portfolio); Natasha de Terán, How the World's Largest Default Was Unraveled, Fin. News, Oct. 13, 2008, http://www.efinancialnews. com/story/2008-10-13/how-the-largest-default-was-unravelled; Press Release, LCH.Clearnet, \$9 Trillion Lehman OTC Interest Rate Swap Default Successfully Resolved (Oct. 8, 2008), available at http://www.lchclearnet.com/media_centre/press_releases/2008-10-08.asp.

115. See Allen, supra note 114, at 1090 ("The default was managed well within the margin $\mathrm{LCH}$ held for Lehman, and LCH did not use any of the default fund . . ."); de Terán, supra note 114 ("Not only did [LCH.Clearnet] not have to tap the default fund, it never even came close to using up the initial margin that had been collected on the Friday morning prior to Lehman's demise.").

116. To ensure that operations could continue, the Federal Reserve offered emergency liquidity to commercial banks who were then encouraged to lend to the struggling CME and lent directly to the parent of the Options Clearing Corporation to ensure its survival. For more detail, see Ben S. Bernanke, Clearing and Settlement During the Crash, 3 Rev. Fin. STud. 133, 148 (1990); Jeremy C. Kress, Credit Default Swaps, Clearinghouses, and Systemic Risk: Why Centralized Counterparties Must Have Access to Central Bank Liquidity, 48 HARV. J. ON Legis. 49, 50 (2011). 
tant-player. ${ }^{117}$ Furthermore, scholars have noted that, even for expert institutions, credit derivatives are notoriously difficult to value and to properly provision for through mechanisms such as collateral cushions. ${ }^{118}$ The May 2012 J.P. Morgan fiasco in the CDS market is case in point. J.P. Morgan, having enjoyed a strong reputation in risk management through the crisis, vastly underestimated the risks that its credit-derivative trades posed for the bank and took positions that exceeded limits established in its internal checks and controls. ${ }^{119}$ Due to their complexity and size, these positions proved very difficult for the bank to exit quickly. ${ }^{120}$ Clearinghouses are unlikely to be immune from such errors, the costs of which may be magnified several fold due to their role as CCPs. Where these errors arise out of faulty models - as in the case of J.P. Morgan ${ }^{121}$-and mistaken assumptions in provisioning for credit risk, the clearinghouse can misprice the extent of its exposures across the board. That is to say, where the clearinghouse does not have a clear idea of how much risk it takes on, its default procedures and risk-management processes are likely to be of little benefit. For example, a clearinghouse may fail to demand enough collateral from its members where it is unable to model the credit risk it assumes or where it has only a partial picture of the extent of its exposures to counterparties. ${ }^{122}$ Further, the clearinghouse depends on its members to supply it with accurate information on the credit-derivative exposures they have assumed. The clearinghouse therefore contends with a potential information deficit where the information it receives from members on their own exposures is stamped by valuation and pricing errors, especially where the clearinghouse has neither the ability nor the authority to verify its sources.

\section{B. CCP GOVERNANCE}

The tenets underpinning clearinghouse-governance norms are well established. ${ }^{123}$ The basic principle is that the clearinghouse be administered for and

117. See generally Allen, supra note 114.

118. See, e.g., Stulz, supra note 8, at 76-78.

119. Pablo Triana, 'Whale' Makes a Big Splash on Risk Models, Fin. Times, May 28, 2012, http://www.ft.com/intl/cms/s/0/b8713aba-a102-11e1-aac1-00144feabdc0.html.

120. See, e.g., Gregory Zuckerman \& Scott Patterson, J.P. Morgan Struggles To Unwind Huge Bets, WALL ST. J., May 18, 2012, http://online.wsj.com/article/SB 1000142405270230387960457741261 3778263918.html (discussing the difficulties of J.P. Morgan unwinding a potential \$5-billion-loss position in the CDS market).

121. Lisa Pollack, A Back Office Failure To Put Right, Fin. Times Alphaville Blog (July 18, 2012, 9:05 AM), http://ftalphaville.ft.com/blog/2012/07/18/1086121/a-back-office-failure-to-put-right/.

122. See supra note 116 (discussing the severe shortage of liquidity suffered by the CME following the 1987 market crash).

123. Kroszner, supra note 92, at 7-9; Kroszner, supra note 78, at 598-604; Moser, supra note 78. For a detailed discussion of clearinghouse governance, see Sean J. Griffith, Governing Systemic Risk: Towards a Governance Structure for Derivatives Clearinghouses, 61 EMORY L.J. 1153 (2012) (discussing the changing norms of clearinghouse governance and the risks these can generate for financial markets), and Craig Pirrong, A Theory of Financial Exchange Organization, 43 J.L. \& Econ. 437 (2000); BANK FOR INT'L SETTLEMENTS, supra note 12, at 8-12. 
by its own members. Historically, clearinghouses have been owned and managed by the main financial institutions populating the market: large banks and investment houses that have the most market share and the most to lose if things go wrong. However, these old structures have seen gradual change: prominent clearinghouses, such as those operated by the DTCC, continue to be user owned, ${ }^{124}$ but recently, exchanges and clearinghouses have come under more diversified ownership. ${ }^{125}$ As analyzed by Professor Chris Brummer, international exchanges have sought to generate efficiencies through international mergers and consolidation in competitive markets. ${ }^{126}$ Reflecting this trend, exchanges have increasingly sought to acquire clearinghouses in order to create vertical economies of scale for executing and confirming trades. Exchanges themselves often organize within the corporate structure of publicly traded companies that sometimes include a host of international-exchange and clearinghouse partners. ${ }^{127}$ Even with these changes, the predominance of the largest financial institutions in clearinghouse governance and membership suggests a high degree of homogeneity in the types of institutions involved, and with that homogeneity comes a high concentration of systemic risk.

Another form of CCP governance exists through membership control. Exchanges and clearinghouses authorize who can use their facilities by scrutinizing membership lists and controlling entry. ${ }^{128}$ Only those institutions that are sufficiently robust can participate. Members are contractually bound to house rules stipulated by the exchange or clearinghouse. Failure to comply can result in a variety of sanctions, including expulsion, which can have serious conse-

124. About DTCC, DTCC, http://www.dtcc.com/about/business/customers.php (last visited Oct. 15, 2012). The DTCC is one of the most established providers of clearing services for equity, bond, and treasury securities in the United States, including clearing securities traded on the New York Stock Exchange. It is owned by its main users, including the prominent broker-dealers in the market.

125. For example, CME Group owns CME Clearing as well as key exchanges such as the Chicago Mercantile Exchange and the Chicago Board of Trade. The clearinghouse for the Intercontinental Trust is managed by directors that form the majority of independent directors of the parent company's board. Matthew Leising, Derivatives Clearinghouse-Ownership Limits Are Dropped from U.S. Bank Bill, BlOOMBERG (Jun. 25, 2010), http://www.bloomberg.com/news/2010-06-25/derivatives-clearinghouseownership-limits-are-dropped-from-u-s-bank-bill.html. Importantly, LCH.Clearnet, the only large clearinghouse that had resisted takeover by an exchange or an exchange-led consortium, has been targeted by various exchanges: potential bidders have included NYSE.Euronext, NASDAQ OMX, and the Singapore Stock Exchange, but ultimately, the London Stock Exchange made a successful bid for control of the London clearinghouse. This transaction is currently awaiting antitrust approval. See Philip Stafford, LSE Set for Majority Stake in LCH.Clearnet, FIN. TimES, Apr. 2, 2012, http://www.ft.com/ intl/cms/s/0/ceab0b0c-7caa-11e1-8a27-00144feab49a.html.

126. For an insightful discussion of this trend and its regulatory implications, see Chris Brummer, Stock Exchanges and the New Markets for Securities Laws, 75 U. CHI. L. Rev. 1435 (2008) (arguing that international mergers between exchanges allow clients to choose an exchange within the group that is subject to the most preferable national legal regime).

127. Id.

128. See, e.g., CME Rulebook, CME Group, http:/www.cmegroup.com/rulebook/CME/ (last visited Oct. 15, 2012); Membership, LCH.CLEARNET, http://www.lchclearnet.com/membership/ltd/default.asp (last visited Oct. 15, 2012). 
quences given the importance of these infrastructure mechanisms. ${ }^{129}$ Entry requirements for clearinghouses are usually even more stringent than those governing access to an exchange. Only a subset of exchange members can participate as members of a clearinghouse. ${ }^{130}$ Clearinghouse members contribute a reserve of collateral to support their activities on the clearinghouse and additional amounts that rise and fall daily depending on the risk level associated with their activities. ${ }^{131}$ In addition, members usually contribute to a general default fund to boost the mutualization potential of the clearinghouse. ${ }^{132}$

Self-regulation, however, has its perils, and clearinghouses are not immune from those dangers. Professor Paul Mahoney has emphasized the positive role that decentralized, private exchanges can play in regulation. ${ }^{133}$ Others have raised concerns about the ability of private exchanges to regulate effectively. Professor Andreas Fleckner, for example, notes that conflicts of interest may pervade where exchanges, often part of publicly traded corporate structures, are regulated by the state but behave like regulators themselves vis-à-vis listed entities. ${ }^{134}$ More broadly, Professors Howell Jackson and Mark Roe have argued that public enforcement of financial-markets laws, as opposed to enforcement via private mechanisms, is positively correlated with deeper capital markets. ${ }^{135}$

Though well established, the governance norms of clearinghouses have attracted special scrutiny. As institutions take on increasingly large and complex risks, their organizational capacity to privately control such forces is subject to question. Private providers such as clearinghouses can fall prey to incentives that privilege profit for the clearinghouse above the public good of risk management. For example, existing member-owners may block access to the facility for incoming users or refuse to process transactions especially advantageous to rivals. ${ }^{136}$ Members may mandate cheaper collateral requirements for themselves

129. See Köppl, supra note 110 , at 16.

130. See BANK FOR INT'L SETTLEMENTS, supra note 12, at 7.

131. See id. at $10-11$.

132. See id. at 24-25; see also Membership: Default Fund Contribution, LCH.CLEARNET, http:// www.lchclearnet.com/membership/ltd/default.asp (last visited Oct. 15, 2012).

133. Mahoney, supra note 94.

134. Fleckner, supra note 89 , at 2579-610.

135. Howell E. Jackson \& Mark J. Roe, Public and Private Enforcement of Securities Laws: Resource-Based Evidence, 93 J. FIN. ECON. 207 (2009). Professors Jackson and Roe provide data to demonstrate that financial-market development correlates positively with strong public enforcement of securities laws. This study works to problematize conclusions put forward by, among others, Djankov and La Porta, who argue that private enforcement is central to the development of strong securities markets. See Simeon Djankov et al., The Law and Economics of Self-Dealing, 88 J. FIN. Econ. 430 (2008); Rafael La Porta et al., What Works in Securities Laws?, 61 J. Fin. 1 (2006).

136. Letter from ABA Sec. Ass'n et al. to David A. Stawick, Sec'y, Commodity Futures Trading Comm'n \& Elizabeth M. Murphy, Sec'y, Sec. \& Exchange Comm'n (Jan. 11, 2011), available at http://www2.isda.org/attachment/MjIzNw = =/Response-to-DOJ-Letter.pdf (describing and rebutting concerns held by the Department of Justice); see also Matt Cameron, Bar Dealers from Owning CCPs, Says European Parliament Report, RisK MAG., Feb. 12, 2010, http://www.risk.net/risk-magazine/news/ 1591821 /bar-dealers-owning-ccps-european-parliament-report ("Proponents of ownership restrictions 
to facilitate lower cost trading and better returns on transactions. Section 765 of the Dodd-Frank Act creates a framework for controlling such conflicts of interest. ${ }^{137}$ The agencies responsible for promulgating rules to implement Section 765 have considered a number of proposals, including mandatory aggregateownership limits for swap-trading and clearing facilities, limits on voting rights for shareholders, and new criteria for the number and qualification of independent directors. ${ }^{138}$

\section{INCENTIVES OF CLEARINGHOUSE MEMBERS}

Despite its importance, the clearinghouse creates powerful incentives for members to pursue individually risky payoffs. As the CCP, the clearinghouse underwrites the trading operations of its members. This creates value for members who enjoy gains by transacting with reduced counterparty risks and trade in a more liquid market with more standardized contracts. Value is also generated where participants inclined to take higher risks can do so knowing that the clearinghouse ultimately underwrites the risk. Such risk taking can generate private gains, lucrative profit, and reputational standing. With weak incentives to monitor each other, instances of individual risk taking are likely to come to light only when things go wrong-and by that time, the recalcitrant player may be too deeply mired in difficulty to be concerned about reproach. When the risk materializes, the clearinghouse finds itself on the frontline to assume the consequences.

Traditionally, clearinghouses have functioned between a small number of specialized players who were well-known to and trade frequently with one another. ${ }^{139}$ This arrangement has not changed over time, nor does it appear that

believe if derivatives dealers own stakes in clearing houses they would have too much influence on the market-either clearing too few trades or too many.")

137. Dodd-Frank Act $§ 765$ (codified at 15 U.S.C. $\S 8343$ (2006 \& Supp. V)).

138. The SEC and the CFTC continue to consult on proposed rules to give effect to the requirements of Section 765 of the Dodd-Frank Act. In original deliberations, the House of Representatives passed a version of Section 765 that included specific limits on aggregate ownership that could be held by all swap dealers (the large banks and investment houses) of swap-trading and exchange facilities. Instead, the SEC and the CFTC were given discretion as to how conflicts of interest may be controlled in the ownership of such facilities. A number of ideas have been put forward for consideration. Some proposals establish limits on the voting rights that may be exercised by swap dealers and owners, whereas others establish restrictions on board composition at new swap-clearing and exchange facilities. The rule-making period, which should have come to a close in January 2011, was extended, thus illustrating the controversy surrounding this issue. Ownership Limitations and Governance Requirements for Security-Based Swap Clearing Agencies, Security-Based Swap Execution Facilities, and National Securities Exchanges with Respect to Security-Based Swaps Under Regulation MC: Reopening of Comment Period, 76 Fed. Reg. 12645 (proposed Mar. 3, 2011) (to be codified at 17 C.F.R. pt. 242), available at http:/www.sec.gov/rules/proposed/2011/34-64018fr.pdf. For more details on the governance alternatives set forth by the SEC for its new Regulation MC, see DAVID SKEEL, THE NEw Financial Deal: Understanding the Dodd-Frank Act and Its (Unintended) Consequences 71-74 (2010); Griffith, supra note 123, at 1218-25; Press Release 2010-190, Sec. \& Exchange Comm'n, SEC Proposes Rules To Mitigate Conflicts of Interest Involving Security-Based Swaps (Oct. 13, 2010), available at http://www.sec.gov/news/press/2010/2010-190.htm.

139. See Kroszner, supra note 78 , at 601 . 
it will change in a significant manner going forward. The reasons, in the case of the credit-derivative market, are twofold. First, the OTC-derivative space for credit derivatives is already concentrated in the hands of a small number of sophisticated players. ${ }^{140}$ This specialization is necessary because parties have traditionally had to trust each other to take risks without the insurance or mutualization advantages offered by a CCP. As evidenced by the 2008 crisis, parties trading credit derivatives often have taken complex and volatile risks. ${ }^{141}$ Second, clearinghouses have allowed only a trusted cohort of market players to take direct membership in their institutions. As CCP, a clearinghouse enters into principal-to-principal, contractual relations with members to complete transactions. As a matter of risk management, clearinghouses cannot take such contractual chances with just anyone. They have established high thresholds in terms of stature and solvency for their direct members and disclaim legal ties to other entities, such as clients of direct members. ${ }^{142}$

Still, clearinghouse members face incentives that can encourage them to pursue risky payoffs at the expense of the clearinghouse. Consider that parties to the clearinghouse contract with each other to guarantee the completion of trades - and to share losses. ${ }^{143}$ Members work towards ensuring that risk is minimized and will not jeopardize the safety of the clearinghouse. For example, if the seller of securities becomes insolvent and cannot provide the securities that it contracted to provide to the buyer, then the clearinghouse, as CCP, must go out into the market and purchase equivalent securities to cover the replacement costs of these securities. If the insolvent seller cannot pay out of its own funds placed with the clearinghouse, then other members bear the responsibility of paying out the replacement costs of those securities through, for example, the default fund. This is the case even if the current market value of the replacement costs is far higher than what the buyer originally paid to the clearinghouse. Where a member fails, this scenario is likely to repeat itself many times over. Collective cooperation should avoid such eventualities: members agree individually and as a group to control the risks that they take on.

This point is nicely illustrated using the game-theory model of the "stag hunt" (or "assurance game"). This game refers to a scenario where payoff depends on cooperation among participants. ${ }^{144}$ If a party defects for reasons of private gain (real or otherwise), then all parties lose as a collective (no stag) though individual prizes can be achieved. ${ }^{145}$ Coordination is a necessary-but

140. Litan, supra note 101, at 14.

141. See Partnoy \& Skeel, supra note 21, at 1024.

142. BANK FOR INT'L SETTLEMENTS, supra note 12, at 10-11.

143. This discussion does not address the possibility that, ultimately, the taxpayer may underwrite the cost of clearinghouse operations on account of the systemically central role that the clearinghouse plays.

144. Douglas G. Baird et al., Game Theory and the Law 35-37 (1994); Brian Skyrms, The Stag Hunt AND the Evolution of Social Structure (2004).

145. The stag hunt refers to a tale of social cooperation and conflict that can be traced back to Jean Jacques Rousseau. It tells the tale of a group of hunters that go out on a hunt and must all cooperate in 
not always attractive-route for parties in their race to catch the proverbial stag. En route, individual actors may veer off to garner societally weaker but individually satisfying gains (hares). In the game, the hunt provides two possible "solutions." 146 The first solution is that parties collaborate to catch the stag and the second solution is that each party pursues her own gains in order to catch hares. The most rational course of action-Pareto optimality-for all actors is to pursue the stag, but in some cases, this may not work where parties are unable to gauge the strategies of others in the game who might choose to pursue the hares instead. ${ }^{147}$ The clearinghouse arguably exemplifies such an assurance game.

The clearinghouse structure makes it difficult to determine how much risk it assumes via its members. This distortion is acute in the case of credit derivatives. First, the member-user model incentivizes member-users to retain the option to defect periodically (or, indeed, more frequently) in the interests of higher returns to be had from the subsidy value offered by the clearinghouse. ${ }^{148}$ Members rationalize this defection as supported by the fact of collateral-and also on the basis that defecting members subsidize others in their trading (and probable defections) by providing funds to populate the clearinghouse's default fund. Where clearinghouses are owned by exchanges, which may be publicly traded, these incentives remain. Higher risk should translate into higher revenues, at least in the near term. Incidence of defection can generate better returns from the clearinghouse, increasing user popularity. Such success attracts business to the exchange and induces a feel-good factor for owners who do not need to support the clearinghouse financially. Ironically, because clearinghouses have functioned well in the past, ${ }^{149}$ investment in detection of individual risk taking may be unattractive: owners have little motivation to expend resources where risk events appear theoretically plausible but practically remote.

order to catch the stag. Catching the stag means that they all eat. Otherwise, an individual hunter can catch a hare for herself and waste the trap that has been set to catch the stag. In that case, only one person eats. BAIRD ET AL., supra note 144, at 35-37.

146. In the stag hunt, there exist two so-called Nash Equilibria. A Nash Equilibrium is the strategy which, for a particular party, represents the best response to the strategy that is deployed by others in the game. For more details, see id., and Eric A. Posner et al., Divide and Conquer 5 (Harvard Law \& Econ., Discussion Paper No. 639, 2009), available at http://papers.ssrn.com/sol3/papers.cfm?abstract id $=1414319$.

147. See Posner et al., supra note 146 , at 4-5.

148. Professor Pirrong has suggested that dealer firms may be unwilling to share proprietary models with the clearinghouse and collective-action concerns may limit the ability of dealers to come together to pool intelligence and call for the development of better models. Interestingly, Professor Pirrong goes on to suggest that most dealer firms, who invariably have complex balance sheets, can use this complexity to hold the clearinghouse at an informational disadvantage and thus be able to use the knowledge of their own complex balance sheets to their advantage. Pirrong, supra note 1, at 37-38.

149. See Allen, supra note 114 , at 1089-90 (chronicling the way in which LCH.Clearnet stood up to the collapse of Lehman Brothers). 
Second, collateral cushions are problematic where credit-derivative trading is concerned. This is true for two reasons. As a matter of accounting, the value of assets offered as collateral can fluctuate depending on how these assets are valued by the market at any given point in time. Clearinghouses demanding collateral ensure that its value is pegged to the market value of the asset, using so-called mark-to-market accounting. ${ }^{150}$ This calculus is performed daily, or even several times per day. In OTC markets, marking security to market is ad hoc $^{151}$ and parties usually have determined among themselves how much and what type of collateral to provide at any given time. Clearinghouses can therefore be vulnerable to swings in asset values, ${ }^{152}$ meaning that collateral cushions can become thinner in value at times of market volatility. Further, clearinghouses must now value contracts that once traded OTC and therefore were not subject to the rigors of daily valuation. A lack of historical benchmarking can contribute to inaccuracies in valuation, at least in the early days of bringing these new securities to clear on regulated markets.

More importantly, credit derivatives are economically and legally complex. This can make the valuation of credit derivatives--whether on the market or even among sophisticated parties-a matter of fine and fraught judgment. ${ }^{153}$ Relying on collateral as protection against defection ex ante may be a dangerous defense against strategic game playing by clearinghouse members. Viewed through the metaphor of the stag hunt, the clearinghouse sets up quite a spectacular problem: what happens if each hunter believes the others are hunting the stag, when they themselves are looking for hares? This dilemma makes the clearinghouse a distinctly troubling proposition.

150. Fair-value accounting or mark-to-market accounting is the practice of valuing an asset or liability based on a consideration of what is "fair" as a market price-meaning, what someone might pay for that asset (or liability) in the market at that time. This means that if the market for an asset is depressed for any reason, then the value of that asset must be marked down and therefore a higher quantity of that asset-or a better quality asset-may be needed if it is pledged as collateral. This principle has been applied under Financial Accounting Standards Board (FASB) Standard Number 157, which requires assets to be valued according to their fair market prices. During the 2008 crisis, this resulted in many toxic securities being valued at next to nothing on account of the depressed market for these securities. In light of this occurrence, Standard Number 157 has since been amended to require that the fair value be determined by an orderly market (that is, not in liquidation mode, which is not an orderly market). However, this change does not do away with the principle of fair value altogether. Asset values may still fluctuate according to market conditions as long as these fluctuations do not take place in a highly stressed market. For more detail, see FASB, Status of FASB Staff Position FAS 157-4 (Apr. 9, 2009), available at http:/www.fasb.org/cs/ContentServer?c=Pronouncement_C\&pagename = FASB\%2FPronouncement_C\%2FStatusPage\&cid=1176154735524; see also Kara Scannell, FASB Eases Mark-to-Market Rules, WALL ST. J., Apr. 3, 2009, http://online.wsj.com/article/SB123867739560682309. html; CCMR REPORT, supra note 19, at 27-30.

151. See, e.g., A Focus on OTC Clearing Innovation, InTERContinental ExChanGe (2009), https:// www.theice.com/publicdocs/ice_trust/Global\%20Investor\%20Magazine.pdf.

152. For accompanying guidance on valuing securities in highly stressed markets, see FASB, Statement of Financial accounting Standards No. 157: Fair Value Measurements (2010) (effective Nov. 15, 2007); FASB, supra note 150 (noting volatile markets may still be orderly).

153. See infra section III.A. 


\section{Reevaluating the Regulatory Paradigm}

While financial markets have long relied on clearinghouses to control systemic risks in the financial markets, they now carry enormous-and unrecognized-legal and economic risks in transacting with credit derivatives. This section sets out a new account of these risks. First, clearinghouses face significant information asymmetries despite the focus on increased transparency in postcrisis legislation. Second, clearinghouses operate in an uncertain legal landscape that limits their ability to protect themselves and the broader market from the inherent volatility of the derivatives market. Third, clearinghouses face the incentive risks created by the private, rent-seeking behavior of their members. With these uncertainties, the risk-management tools clearinghouses rely on to protect themselves-and the financial system as a whole-may be sorely unsuited to match the complex and novel constellation of challenges they face in the market. ${ }^{154}$

\section{A. COORDINATION AND INFORMATION ASYMMETRIES}

Clearinghouses are designed to bring greater transparency to the market. However, the complexity of the information conveyed in credit derivatives renders transparency of little value, where understanding and internalizing the significance of the information poses a considerable challenge for the market. Of course, in theory, with the existence of the clearinghouse, market participants should have a more accurate reading of the risks they assume. Where persons develop information-sharing mechanisms, there exists less tactical guessing and uncertainty as to whether others will pursue the rational, Paretooptimal solution. ${ }^{155}$ Parties can all agree on the most effective mechanism to achieve the desired goal, rather than chase individual rewards. ${ }^{156}$ The staghunt analogy is again helpful in understanding this situation. Unsurprisingly, studies have noted that, where parties have information regarding others participating in the stag hunt and communicate with them, they usually arrive at the rational outcome rather than at a suboptimal solution. ${ }^{157}$ Clearinghouse members are ideally placed to avoid individual, suboptimal risk taking by sharing information through the clearinghouse. Through this line of reasoning, clearinghouses are critical to parties' ability to develop rational strategies that reduce

154. Cf. Letter from Hal Scott, President \& Dir., Comm. on Capital Mkts. Regulation, to Gary Gensler, Chairman, Commodity Futures Trading Comm'n (Sept. 15, 2010) (discussing conflicts-ofinterest rules for derivatives clearinghouses and describing the collapse of the clearinghouse as an event akin to Chernobyl for the financial markets).

155. See supra note 147 and accompanying text.

156. See Posner et al., supra note 146 , at 5.

157. Id. See generally Jack Ochs, Coordination Problems, in The Handbook of ExPERIMENTAL Economics (J.H. Kagel \& A.E. Roth eds., 2005). But see Joseph Farrell, Cheap Talk, Coordination, and Entry, 18 RAND J. EcoN. 34, 39 (1987) (suggesting that "the conflict inherent in the game prevents even unlimited communication from achieving perfect coordination"). 
risky trading. However, the usefulness of this information sharing depends on two assumptions. First, the information must be comprehendible such that it will help parties gauge the strategies of other participants in the clearinghouse. Second, parties must use this information in the exercise of the optimal strategy -in acting rationally - and avoid chasing hares in the near term. Both these assumptions can be contested in the context of the clearinghouse's operations and, specifically, with respect to the trading of credit derivatives.

\section{Assumption One: Information Must Be Useful and Comprehendible}

Much has been made regarding the greater transparency that clearinghouses bring to fix the opacity of the OTC-derivative market. Policymakers ${ }^{158}$ and scholars ${ }^{159}$ promote the clearinghouse as a mechanism to reduce the information asymmetries that pervaded the market in the lead up to the crisis and was evidenced by the Lehman Brothers ${ }^{160}$ and AIG fallouts. ${ }^{161}$ Consternation caused by perceived black holes of information in the OTC market has led to legislative action. Mandatory trade reporting ${ }^{162}$ is now central to reform measures in these markets in the postcrisis world. However, the focus on transparency obscures an essential and simple point: reporting does not guarantee that private parties, including the clearinghouse and its members, will internalize the gravity of information released. Even credit-rating agencies, designed to be the market's expert information disseminators, were too slow to grasp the extent of credit risk in the market during the 2008 crisis. ${ }^{163}$ In view of the systemic position of clearinghouses and the reliance placed on them, the costs of even small failings in this regard would invariably be enormous.

158. See G-20 PitTsBurgh Summit, supra note 2, at 7.

159. See, e.g., Robert R. Bliss \& Robert S. Steigerwald, Derivatives Clearing and Settlement: A Comparison of Central Counterparties and Alternative Structures, ECON. PerSP., 4th Qtr. 2006, at 27-28 (noting that CCPs provide centralized book-keeping functions for their trades); CCMR REPORT, supra note 19 , at 7-8; Acharya \& Bisin, supra note 112, at 5 .

160. Aline van Duyn et al., The Lehman Legacy: Catalyst of the Crisis, Fin. Times, Oct. 12, 2008, http://www.ft.com/cms/s/0/ea92428c-9887-11dd-ace3-000077b07658.html.

161. See Morgenson, supra note 72; Acharya \& Bisin, supra note 112, at 4.

162. See supra note 108 (citing Dodd-Frank Act $\S \S 729,766(\mathrm{~b})$ ). However, it should be noted that mandatory trade reporting will likely result in increased information available to regulators rather than others in the market. The Dodd-Frank Act stipulates that only basic data regarding prices and notional amounts must be publicly reported, subject to possible delays for large transactions. The question remains as to whether regulators should share repository data with the market. Note the case of the Trade Reporting and Compliance Engine (TRACE), a reporting hub established for corporatebond data. TRACE is operated by the industry broker-dealer regulator, the Financial Industry Regulatory Authority (FINRA). When TRACE was first established, there were considerable time lags between the time of the trade, the time the trade was reported to TRACE, and the time this information was made available to the market. As TRACE has become more established, the time lags between trade, reporting, and dissemination have reduced considerably and may be regarded as virtually negligible. For more information on TRACE, see Fang Cai et. al., Institutional Herding in the Corporate Bond Market 5-6 (Fed. Reserve Bd. Rep., Nov. 2010).

163. E.g., Patrick Jenkins, Triple A Is Old Hat for Banks, FIN. TIMEs, Dec. 6, 2011, http://www.ft.com/ int $/ / \mathrm{cms} / \mathrm{s} / 0 / 7 \mathrm{~b} 912824-2035-11 \mathrm{e}-9878-00144$ feabdc0.html (suggesting credit-agency ratings were not necessarily reliable indicators of a bank's health). 
The reasons for these challenges are manifold. To start with, historical evidence has not been encouraging. Commentators note that information on credit-derivative trades was widely available and disseminated in the market prior to the 2008 crisis. ${ }^{164}$ Not only were private providers active in collecting it, ${ }^{165}$ but also market indices ${ }^{166}$ referencing derivative and mortgage-backedsecurities data were leaking clues regarding the gloom about to engulf the markets well before the eventuality came to pass in $2008 .{ }^{167}$ Clearinghouses themselves were collecting data on credit-derivative activity during this time as well. Professors Bliss and Steigerwald stated in 2006 that the DTCC was developing a database of "golden copies" for all credit-derivative trades. ${ }^{168}$ These golden copies were designed to provide a master, legally binding version of credit-derivative agreements between parties. The DTCC sought also to provide information to counterparties where they may have been overexposed to particular underlying assets. ${ }^{169}$ To suggest that only minimal information existed for OTC-derivative markets prior to recent reforms is short of the mark.

Internalizing the implications of information requires grappling fully with its complexities. Scholars have suggested that data expressed in relation to credit derivatives may have been too complicated to be absorbed into and reflected in usual market indicators. Professor Robert Bartlett contends that the market poorly internalized disclosures that were made by monoline insurers ${ }^{170}$ on their worsening exposure in the CDS market (as compared to the disclosures regarding monoline insurers' losses in the corporate-bond market, to which the market reacted more predictably). ${ }^{171}$ Bartlett notes one explanation for the lack of internalization: data on CDS exposures were too complex to compute effec-

164. See Scotr, supra note 31 , at 858-59.

165. Notably, Markit, an information provider owned by several hedge funds, was active in collecting and providing information on credit-derivative trades. About Markit, MarkIT, http:/l www.markit.com/en/about/about-Markit.page (last visited Oct. 15, 2012); see also ScotT, supra note 31, at 858 (noting that Markit obtains the marked-to-market valuations for every position of thirty-five to forty financial institutions and then "subjects this data to an analytical process involving multiple algorithms, which in turn results in end-of-day pricing information for end users").

166. The $\mathrm{ABX}$ indices, among others, were yielding information on the downturn in the mortgage market. E.g., Gorton, supra note 64, at 20.

167. See, e.g., id. at 23.

168. See Bliss \& Steigerwald, supra note 159 , at 27.

169. See id.

170. Monoline insurers are insurers that have traditionally specialized in providing insurance for bond issues, particularly in the municipal-bond market. Increasingly, they have provided insurance for more complex securities such as mortgage-backed securities. They also sold credit protection for toxic asset-backed securities through CDSs. In the crisis, this industry suffered large losses owing to their role in insuring toxic securities and in providing CDS protection. See generally Christine Richard, Ambac, MBIA Lust for CDO Returns Undercut AAA Success, BLOOMBERg (Jan. 22, 2008), http://www. bloomberg.com/apps/news?pid=newsarchive\&sid =aw 1 Oh4B0Wvv8.

171. Robert P. Bartlett III, Inefficiencies in the Information Thicket: A Case Study of Derivative Disclosures During the Financial Crisis, 36 J. CORP. L. 1, 3 (2010). 
tively. ${ }^{172}$

Communication and collaboration needed to optimally achieve systemic soundness can also fall short. A further factor hardens this outcome. More fully discussed below, parties can structure their credit-derivative transactions to opportunistically display certain information to the market. ${ }^{173}$ The transaction data can show that the member is not taking on risk, when in fact its exposures may be dangerous. Parties can thus hide the true extent of their exposures. For example, they can trade more risk than they should without facing punishment from the clearinghouse (or their peers) and without revealing the true extent of their risk taking.

The OTC market will not disappear with the advent of central clearing. If risks inherent in a credit-derivative contract are too complex to be traded on-exchange and cleared using a clearinghouse, they may qualify to remain off-exchange. ${ }^{174}$ This, by itself, seems straightforward. Nonstandard risks are, by their nature, more illiquid and attractive to a smaller and more specialized segment of the market. Postcrisis regulation is careful to include the OTCderivative market within its purview. Parties trading OTC must report their trades, ${ }^{175}$ and they also must ensure that they maintain collateral cushions that are thicker than the cushions they would need if they were using an exchange and clearinghouse. ${ }^{176}$

Still, the OTC market provides room for creative trading and risk reporting. Take the case of parties structuring a hedge in the OTC market, which references a large portfolio of mortgage-backed securities, some risky and some less so. As part of this trade, two parties agree to buy and sell the risk attaching to a very large loan. Party $A$ has bought mortgage-backed securities and wishes to sell the risk to Party $B . B$ is happy to take the exposure: it gets a fee, and it believes the mortgage market is on the up (so it should not have pay out to $A$ ). At the same time, $B$ decides to sell the risk of one of its large loans to $A$ because, for example, $B$ has an overcrowded balance sheet and thus seeks to offload its risk. $A$ thinks it will benefit from the exposure to this loan. So the basic contours of this OTC transaction might look like this:

172. Id.; see Pirrong, supra note 1 , at 35 (noting the challenges in pricing credit derivatives owing to their complexity and their recent entry into the market).

173. See infra note 177 and accompanying text.

174. See Dodd-Frank Act $\S 729$ (codified as amended at 7 U.S.C. $\S 6 q-6 r$ (2006 \& Supp. V)) (discussing reporting requirements for swaps not accepted by any derivatives clearing organization).

175. See id. $\$ 731$ (codified as amended at 7 U.S.C. $\$ 6 s(2006 \&$ Supp. V)).

176. See id. $\$ 731$ (e)(1) (codified as amended at 7 U.S.C. $\$ 6$ s (2006 \& Supp. V)). 


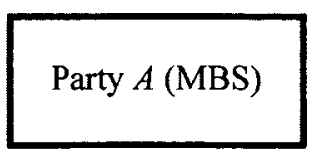

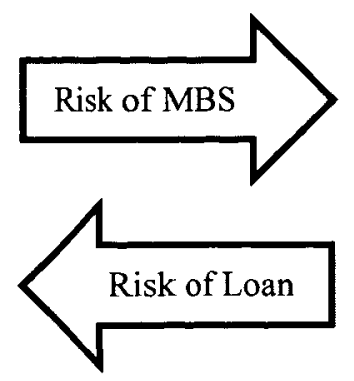

Figure 2

Party $B$ (Loan)

As a first and fundamental point, even in this relatively simple structure, parties can present the information displayed in Figure 2 in a variety of ways. When reporting their exposures in the OTC market, parties could well choose to report each transaction separately. ${ }^{177}$ This means that the market receives complete information on each individual transaction but may not receive data on any offsetting positions that each party has against the other. Alternatively, parties could provide data expressing only their net risk to one another (that is, the difference between what each party would have to pay out to each other if the underlying reference assets all went bad).

Second, this reporting does not clarify the entire composition of the risk: for example, $A$ may have a higher exposure than $B$ after the trade because the dollar value of the loan is large and it is an undiversified obligation. $B$, on the other hand, may be more likely to have to pay out because the portfolio of MBSs could be risky in that it shows commonality between asset classes (for example, real estate). If there is a sharp downturn in the housing market, then holding different risk types of MBSs is moot because securities will all become more risky and default simultaneously.

When reporting to the market, how should degrees of system-wide risk attaching to different types of securities be computed? Some form of systemic value to the risk can exist where, for example, interest-rate volatility increases the costs of servicing loans for borrowers. As a result, many borrowers might default at once. Moreover, pricing credit derivatives can be deeply problematic, owing to the basic volatility of credit risk. ${ }^{178}$ Simply put, strategic disclosure of information adds to existing difficulties in the understanding and pricing of these instruments. The clearinghouse thus faces high information asymmetries, hampering its ability to correctly calculate the collateral it needs to protect its exposures owing to this strategic behavior. This informational deficit also makes it much more difficult for the clearinghouse to stipulate appropriate position

177. See Holger Spamann, Derivatives Trading and Negative Voting 2-3 (Harvard Ctr. for Law, Econ. \& Bus., Discussion Paper No. 730, 2012), available at http://papers.ssrn.com/sol3/papers.cfm? abstract_id $=2144552$ (discussing various strategies that OTC-derivatives traders can use to camouflage their trades).

178. See infra section III.A.4. 
limits for individual members.

Even when there is consistency in reporting categories (for example, if parties are mandated to report net exposure), comparability of data in the OTC space is limited, given that each transaction can be unique and nonstandard, and the composition of exposures can be tailored and represent a variety of creditrisk profiles.

Clearinghouses must also confront the risks of their members' activities in the OTC market. The OTC market-though not completely opaque-provides room to creatively use and display information. Notably, the market for complex derivatives rests in the hands of the larger financial houses. ${ }^{179}$ These players are likely to be active as members of clearinghouses and as dealers in the OTC-derivatives market. The information that the clearinghouse receives in such cases may be incomplete for two key reasons: partial twice over because (1) information in the OTC space references complex trades and may be presented in various nuances; and (2) the clearinghouse may not have a full picture of the risk it takes on, where a part of the risk pertains to a cleared transaction continues to exist in the OTC market. That is to say, parties may splice and dice a large transaction to trade only some of its risk through a clearinghouse, while leaving the remainder of the risk in the OTC market.

Returning to the transaction between Party $A$ and Party $B$ referenced above, say Party $B$ decides to trade a part of its exposure on the MBS using a credit derivative cleared using a clearinghouse. ${ }^{180}$ The basket of securities referenced by this credit derivative is low risk. Party $C$ agrees to protect Party $B$ in the event Party $B$ suffers a loss on this low-risk basket of securities. Party $C$ believes default to be unlikely and will benefit from the premium Party $B$ must pay for protecting itself against the possibility of loss. This seems like a win-win for Party $C$. Critically, the information entering the clearinghouse on the derivative-and disseminated across its membership-relates to the lowrisk basket of securities. The message conveyed to members is therefore consistent with the continuing assurance game, namely that Party $B$ is trading low-risk securities through the clearinghouse. Members see that Party $B$ appears to be playing by the rules. In reality, however, the risk facing Party $C$-and as $C C P$, the clearinghouse-is a great deal more complex. In fact, the risk entering the clearinghouse includes the poor-quality tranche of securities failing, possibly leading to the failure of the high-quality, low-risk basket of securities. Party $B$ also faces the possibility that Party $A$-its counterparty in the OTC marketmight fail. As a result, its own exposure increases because its exposure to the big loan is no longer hedged. Therefore, Party $B$, too, might fail. The vulnerability of the securities to systemic risks incrementally increases depending on how inherently risky they are. Where the basket of securities is low risk, then chances are that increases in interest rates, for example, may be better absorbed.

179. Litan, supra note 101, at 14.

180. See Dodd-Frank Act $\$ 731$ (codified as amended at 7 U.S.C. $\S 6 \mathrm{~s}$ (2006 \& Supp. V)). 
The inverse applies to the poor-quality tranche of MBSs. Nevertheless, both sets of securities are interconnected-the deeper the losses faced on the poor-quality tranche, the higher the chances that Party $B$ also faces losses on its better quality securities. ${ }^{181}$ The "safe" transaction undertaken with Party $C$ can be risky-and parties do not receive fulsome information to recognize how much risk the other is actually trading. This means that, even with the clearinghouse providing a means to communicate, information flow is far from perfect. It can be used selectively and creatively to hide one's play-making the goal of finding the proverbial stag that much more elusive.

\section{Assumption Two: Information Must Be Used Rationally}

In addition to the assumption that information provided by the clearinghouse must be useful and comprehendible, the clearinghouse model assumes that parties sharing information will use that information rationally. This implies that players will not run after the private risk that comes at the expense of the clearinghouse. It is not clear whether this rationality assumption holds true in the context of derivatives trading. A meaningful discussion of some of the behavioral scholarship relating to the financial markets is outside the scope of this Article. Suffice to mention that scholars have long diagnosed irrational exuberance as a salient feature of the finance and securities markets, and short-term incentives (such as those fostered by executive-compensation schemes) only serve to add fuel to this fire. ${ }^{182}$

In the specific context of derivatives, Professor Henry Hu argues that derivatives traders may be especially vulnerable to these waves of irrational exuberance. ${ }^{183} \mathrm{Hu}$ has suggested that cognitive biases of players are tilted against an accurate appreciation of risk-and may instead be oblivious to extremes of risk taking. ${ }^{184}$ In this vein, derivatives dealers can find themselves taking risks

181. See supra Part I. Parties are often paid in a set order from income received from a pool of underlying mortgages. The higher one is in the order, the safer it is. The lower one goes in the order, the riskier one's exposure becomes. Where the pool of mortgages starts to fail, however, the chances of being paid even in the higher tranches start to diminish as losses in the pool of mortgages grow.

182. See, e.g., Alan Greenspan, Chairman of the Fed. Reserve Bd., Address to the Annual Dinner and Francis Boyer Lecture of The American Enterprise Institute for Public Policy Research (Dec. 5 , 1996) (discussing the impact of irrational exuberance on asset values and popularizing the term "irrational exuberance"). See generally RoBert J. Shiller, IrRational Exuberance (2d ed. 2006). In the legal literature, the behavioral economics canon has challenged the rationality assumptions of economic actors. The work of Professors Russell Korobkin, Cass Sunstein, Christine Jolls, and Don Langevoort, among others, has established that actors can be influenced by and act according to a variety of biases, assumptions, and motivations. See Donald C. Langevoort, Taming the Animal Spirits of the Stock Markets: A Behavioral Approach to Securities Regulation, 97 Nw. U. L. Rev. 135 (2002); Christine Jolls, Behavioral Law and Economics (Yale Law Sch., Pub. Law \& Legal Theory Working Paper No. 130, 2006). A detailed literature review in this area is beyond the scope of this Article.

183. Henry T.C. Hu, Misunderstood Derivatives: The Causes of Informational Failure and the Promise of Regulatory Incrementalism, 102 YALE L.J. 1457 (1993) (arguing that derivatives trading gives rise to irrational trading behavior).

184. Id. at 1464, 1487-91 ("[D]ecisionmakers are not always economically rational. Studies have shown that individuals frequently rely on cognitive shortcuts (heuristics and biases) to solve complex 
where they rationally should not do so-because they may be cognitively biased against appreciating the likelihood of these risks materializing. ${ }^{185}$ During the 2008 crisis, Hu contends that traders in the market failed to account for extreme risks in the financial models that they used to determine exposures, until these came famously undone all at once. ${ }^{186}$

Notwithstanding these potential biases, the clearinghouse is designed, in theory, to prevent its members from taking high individual risks and to discipline them when they do. After all, members have their own money on the line in cases where others take on too much risk. Thus, they should be motivated to watch out for instances of exuberance in others and to invest in better models that are sensitive to risk taking. ${ }^{187}$ At the same time, however, the clearinghouse makes the temptation to defect all the more powerful because it provides a means for parties to enjoy subsidized risk taking. The clearinghouse generates its own path dependencies. ${ }^{188}$ Where members rely on the clearinghouse to police exposures, they are less motivated to invest private resources in overseeing others' behavior. Accordingly, without mechanisms to pressure members to act conscientiously in their trading and disclosure practices, the utility of clearinghouses as purveyors of transparency remains under serious question. As set out in Part IV, this Article suggests reforming the design and institutional orientation of the clearinghouse to exert soft pressure on clearinghouse members to better check their distorted incentives.

\section{B. CCP AND DEBT GOVERNANCE}

The clearinghouse faces an unfamiliar legal landscape. Despite the vast economic risk that the clearinghouse concentrates in its institution, it lacks basic legal tools common to lenders that help them understand and safeguard their exposures against underlying borrowers. This derivatives deficit is a novel problem related to the clearing of credit derivatives. It arises because credit derivatives are able to separate the economic risk in an underlying debt instrument, such as a loan or bond, from the legal rights that attach to that interest (such as the rights to obtain information from a borrower, to enjoy standing in

problems under conditions of uncertainty or incomplete information. Sometimes these shortcuts are irrational and mistaken." (footnotes omitted)).

185. Id. at 1487-91.

186. Over-the-Counter Derivatives: Modernizing Oversight To Increase Transparency and Reduce Risks: Hearing Before the Subcomm. on Sec., Ins., \& Inv. of the S. Comm. on Banking, Hous., \& Urban Affairs, 111 th Cong. 58-64 (2009) (statement of Professor Henry Hu).

187. Recall that the models institutions have used to estimate credit risk are far from fail proof. They have been revealed as having been based on inaccurate assumptions, for example, in failing to factor in a downturn in the housing market. Carrick Mollenkamp et al., Behind AIG's Fall, Risk Models Failed To Pass Real-World Test, WALL ST. J., Nov. 3, 2008, at A1; see also Pirrong, supra note 1.

188. Cass R. Sunstein, The Law of Group Polarization (Univ. of Chi. Law Sch., John M. Olin Law \& Econ. Working Paper No. 91, 1999), available at http://ssrn.com/abstract=199668 (arguing that group deliberation leads to a more extreme point of view to reinforce any prejudgments that the group may espouse). 
bankruptcy proceedings, or to enforce security rights). Clearinghouses can be left holding the credit risk of an underlying security without enjoying the protection of basic legal rights, leaving them without a key means of managing their risk. While clearinghouses have not traditionally been in the business of holding such legal rights vis-à-vis underlying borrowers, the novelty of creditderivative instruments and the extraordinary risks they pose for the clearinghouse and the market necessitates a new perspective.

Credit risk has always been special in the eyes of the law. Credit risk underlies the debtor-creditor relationship and its volatility is controlled by, among other things, contract law, property law (for example, for certain secured rights), and the law of insolvency. The clearinghouse operates within the esoteric regulatory milieu of the financial markets. However, as the CCP, the clearinghouse faces new legal regimes to which it is not accustomed-and for which it is unsuited. The CCP stands at the center of a derivative contract. Irrespective of whether a buyer or seller fails, the CCP carries the risk of contractual performance with respect to the counterparty. This means that, unless the CCP can quickly offload the economic risk exposure of a CDS contract to another market player, the CCP will inherit those risks.

In the following, simplified example, Party $B$ sells credit protection on Company $C$ to Party $A$, a bank that has made a large loan to Company $C$. This CDS is cleared through a CCP. This may be illustrated as follows:

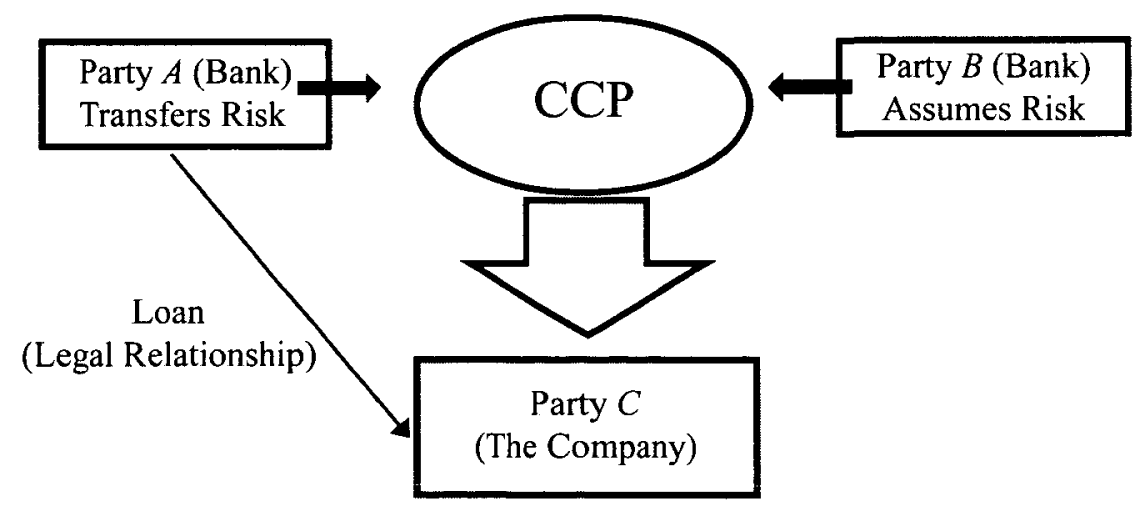

Figure 3

In this scenario, were $C$ to fail, $A$ would be a so-called empty creditor ${ }^{189}$ of $C$, meaning, in the terminology of Professors $\mathrm{Hu}$ and Black, that $A$ would hold certain legal rights and obligations of $C$ but would have no economic exposure. As the protections seller, $B$ holds the exposure on this loan. This contract is cleared by the clearinghouse. As described earlier, the CCP is the buyer to each seller and the seller to each buyer. ${ }^{190}$ The CCP promises to perform vis-à-vis $A$

189. See generally Hu \& Black, Equity, supra note 25.

190. See supra note 13 and accompanying text. 
(that is, to pay out on Company $C$ 's failure) and also promises to perform with reference to $B$ (that is, to pay a regular premium to $B$ for protecting $A$ ). In normal times, the $\mathrm{CCP}$ should do no more than ensure the continuing processing of this contract. However, when things go wrong, the CCP is left holding risk on the underlying transaction and, in a distressed market, faces high costs in selling this risk to another party.

Take the case of a system-wide crisis that causes Company $C$ to default on its loan and also causes $B$ to become unable to perform. In bad times, the CCP is left holding the economic risk of the failed transaction: it must pay $A$ for the losses suffered on the loan. The implications unravel as follows: First, as illustrated above, the CCP holds the economic exposure on the loan, but it does not have any legal rights vis-à-vis $C$. Its legal rights derive indirectly from its relationship with $A$. Whereas a bank may have been able to restructure or reschedule a loan with its borrower to avoid outright default, the CCP lacks direct legal tools to mitigate its losses. By contrast, $A$ has no incentive to try to restructure where it knows it will be repaid in any event under its CDS-and especially if it knows it will be repaid only if Company $C$ goes bankrupt, rather than if Company $C$ is restructured. ${ }^{191}$ If Party $A$ receives payment under the CDS from the CCP, it has little incentive to take a responsible part in bankruptcy proceedings to recoup losses. The CCP faces an uphill battle in attempting to take a seat at the creditor's table in bankruptcy where its exposure to $C$ is indirect and its legal rights vis-à-vis $C$ are circuitous.

Second, an interesting twist arises in the case of a distressed financial market where both $A$ and $B$ begin to suffer large losses simultaneously. ${ }^{192} C$, however, weathers the storm and remains financially healthy. In the interim, the CCP's exposure to $C$ starts to rise incrementally as $A$ falls into ever greater states of disrepair. $A$ has no incentive to monitor $C$ - and $B$ may have an incentive but no legal means to assess its risk to $C . B$ may also be unmotivated to act if it knows that it will not have to pay out (because $C$ is doing well). If $B$ is likely to go bust

191. Professor $\mathrm{Hu}$ has argued that Goldman Sachs was likely an empty creditor of AIG, where it had essentially hedged its exposure to AIG. In particular, Professor Hu notes that Goldman Sachs had made statements that its exposure to AIG was not material, even though AIG eventually paid $\$ 7$ billion (through the assistance of the Federal Reserve System and the Treasury) to satisfy its obligations to Goldman Sachs. Hu, supra note 68; see Henry T.C. Hu \& Bernard Black, Debt, Equity and Hybrid Decoupling: Governance and Systemic Risk Implications, 14 EUR. FIN. MGMT. 663, 682 (2008) ("Even a creditor with zero, rather than negative, economic ownership may want to push a company into bankruptcy, because the bankruptcy filing will trigger a contractual payoff on its credit default swap position."); see also Bolton \& Oehmke, supra note 25, at 2617-19 (arguing that a CDS may strengthen a creditor's hand, allowing it to enforce greater debtor discipline by taking a tougher stance against debtors and forcing some repayment).

192. In these circumstances, regulators like the FDIC may undertake corrective-action measures pursuant to mandatory bank-resolution regimes. More generally, in the event of default, derivatives contracts may be closed out and terminated under the Bankruptcy Code. Even with netting and setoff of derivative contracts, however, a party may still be left with a net exposure that it is unable to pay. See 11 U.S.C. $\S \S 362(\mathrm{~b})(17), 362$ (b)(27), 560 (2006) (derivatives and repurchase parties liquidate collateral in their possession); id. $\$ \$ 546(\mathrm{~g})$, (j) (exemption from preference rules); id. $\$ \$ 553(\mathrm{a}), 560$ (wider option to set off). 
itself, it may not care about the risks it is taking. However, the CCP's exposure increases and the CCP has no legal tools to monitor $C$, to seek information from $C$, or to take other steps to protect its position. ${ }^{193}$ The CCP is powerless legally to tackle important sources of underlying exposure-increasing the valence of risk that it faces. The broader questions loom large: how should the CCP act in such cases? What kind and quality of role can it assume in debt governance relating to entities that are not its members and may be far removed from the rarefied world of complex derivatives? ${ }^{194}$

Third, in approaching these questions, it is useful to revisit the deeper workings of the clearinghouse. When members depend on each other to pursue low-risk outcomes, the risk-sharing and risk-underwriting functions generate incentives for members to use the clearinghouse more profitably and opportunistically. This is important for debt governance as well. If members are getting into trouble, any lingering motivation they may have to play by the rules is diminished. The risk will, after all, be borne by others. A failing firm may have to (or may wish to) provide only partial or inaccurate information to the clearinghouse to ensure it continues to be perceived as a player in the game. Indeed, as discussed earlier, the continued presence of the OTC market for CDSs allows traders to fragment the ways in which trading information is presented to the clearinghouse, quite separate from the risk generated by their problematic incentives. In debt governance, the significance of this information is especially high. CCPs benefit from learning as much as they can about an underlying reference entity or asset to better understand their overall risks. A high-resolution picture of their economic and "legal deficit" risk is necessary to internalize costs of this risk and decide how best to act. From a pragmatic standpoint, this information is critical to calibrating appropriate levels of collateral to keep as protective buffer against these risks and determining how best to exercise risk-management tools at the clearinghouse's disposal (such as establishing appropriate position limits for members). However, when CCPs need this information most acutely, member incentives to provide it are at their lowest. In addition to better information, reform requires reconceptualizing the bundle of legal rights available to clearinghouses to safeguard against the swath of economic risks that can come to rest in their institution during a crisis. Curing this legal deficit undergirds the regulatory solution proposed in Part IV

193. For example, the CCP may benefit from taking security, talking to Company C's other creditors, or ensuring Company $C$ is up-to-date with its representations and warranties.

194. See, e.g., Douglas G. Baird \& Robert K. Rasmussen, Control Rights, Priority Rights, and the Conceptual Foundations of Corporate Reorganizations, 87 VA. L. REv. 921, 922 (2001) ("[T]he central focus of corporate reorganizations should... [be] how the firm's assets are used and who controls them."); Ronald J. Mann, Strategy and Force in the Liquidation of Secured Debt, 96 MicH. L. Rev. 159, 160 (1997) ("The most important effects [of secured lending] arise from the capacity of a grant of collateral to influence the actions the parties take short of forced liquidation of collateral."); Jay Lawrence Westbrook, The Control of Wealth in Bankruptcy, 82 Tex. L. REv. 795, 797 (2004) ("[C]ontrol of the bankruptcy process, rather than formal rules of security and priority, is the key to understanding both secured-credit and bankruptcy law ...."). 
of this Article.

\section{THE COST OF INCENTIVE RISKS}

The securitization process as well as the credit-derivative market create additional risks on top of the basic risks that they reference (such as those of an underlying asset). When investors take on exposures to securitized bonds, these investments are comprised of the risks of the underlying loan portfolio in addition to counterparty risk. ${ }^{195} \mathrm{~A}$ separate risk is also significant: incentive risk. This is the more intangible and unquantifiable risk that arises on account of parties having limited interest in or ability to monitor the actual credit and counterparty risks that they are taking because these can be traded away easily.

Incentive risks are significant for the clearinghouse. First, while presenting societal benefits, securitization also allows lenders to extend loans knowing these can be sold on to investors. ${ }^{196}$ Similarly, CDS sellers promise protection because they expect to be able to trade away or hedge the risk that they have assumed. The implications of this incentive risk are, among others, that more credit may have been extended than is desirable and, moreover, that it has been extended recklessly without robust due diligence. The clearinghouse must face the consequences of this risk-notably, clearing derivatives written on poorquality assets and the likelihood that parties will continue to take on such exposures.

Second, it is not clear whether the clearinghouse can "see" this risk coming. The clearinghouse is closest, legally and transactionally, to its members. Its ability systematically to obtain information from actors other than its members is limited. Though the clearinghouse might lean on its members to get data, the information that it obtains remains secondhand and subject to defects (for example, information loss, poor record keeping, or incomplete data recording). Returning to the assurance game discussed in section II.A.3, it is not always in members' interests to provide the CCP with sensitive information on their own clients' activities. In a small market, members compete with each other. Where their clients are able to undertake more activity, even if it is risky, that activity holds out the temptation of higher revenues. In the cost-benefit calculus, the clearinghouse eventually subsidizes the costs of risks taken down the line.

Third, the question arises: what can the CCP do to control the incentive risks? Given that the CCP is subject to these incentive risks, how might it keep itself safe? An initial and obvious step requires that the CCP tell its members to discipline clients down the transaction chain. Clearinghouse members comprise some of the largest and most powerful firms. Their disciplining influence

195. See supra note 13 and accompanying text.

196. Jaffee et al., supra note 39, at 68. Jaffee reports that, between 2001 and 2007, subprime origination tripled from $\$ 190$ billion to $\$ 600$ billion annually. During that same time period, the proportion of securitization went from $50.4 \%$ to $80.5 \%$, suggesting that these subprime loans were ending up in structured, securitized products. 
may be persuasive. That said, in the assurance game, it is not clear whether this is entirely reliable. Some members may be more diligent than others. Their diligence may result in them garnering lower profits and also subsidizing the bad behavior of other members. Each member should display a roughly equal level of conscientiousness-otherwise, member incentives to defect will be considerable. If the clearinghouse cannot fully rely on its members, then what is left? Arguably, little. With this in mind, the clearinghouse invariably would benefit from better engagement with a wider cohort of market actors to garner access to information about their activities and check instances of reckless behavior.

\section{SHAKY SECURITY}

The clearinghouse mitigates the risks of trading by setting aside enough capital to protect itself in case of default. However, its ability to keep itself (and the market) safe depends on whether the clearinghouse is able to measure and price risk accurately enough ex ante to safeguard against risk's worst consequences. In light of the pervasive information asymmetries seen in modern markets, the derivatives deficit, and the incentive risks outlined above, the clearinghouse faces considerable challenges in correctly estimating its risks and the amount of capital it might need as a protective buffer.

One important advantage conferred by the clearinghouse is its ability to reduce the risks of trading. Not only are parties trading with a reliable counterparty, but reservoirs of collateral buffer their activity and mitigate risk. ${ }^{197}$ They can be sold easily to offset the costs incurred by the clearinghouse. More than that, each trade the clearinghouse processes is marked to market daily. ${ }^{198}$ This means that the clearinghouse values its contracts daily ${ }^{199}$ and if this value rises and falls, its fluctuations must be matched by adjusting levels of collateral. ${ }^{200}$ The point to note is that the clearinghouse is designed to provide a near failure-free environment. Collateral cushions are intrinsic fallbacks in the architecture of this institution.

However, confidence in the clearinghouse's ability correctly to determine the amount of collateral it needs assumes that the clearinghouse can correctly understand the risks it faces and, furthermore, is able to internalize its costs. These assumptions rest on shaky ground. First, in order to determine how much collateral each member must contribute, the clearinghouse must possess an accurate calibration of its needs. This is far from the case when the clearinghouse transacts in credit derivatives. This Article has shown that, in trading credit derivatives, the clearinghouse faces a far more problematic mixture of risks than it ever has in its history-including, for example, incentives that are

197. See Pirrong, supra note 93 , at 2-3.

198. For an account of how this works operationally, see Pirrong, supra note 1, at 19.

199. See, e.g., Collateral Types Accepted for Futures, Options \& Select Forwards, CME Group, http://www.cmegroup.com/clearing/financial-and-collateral-management/ (last visited Oct. 16, 2012).

200. See, e.g., Morgenson, supra note 72; Walsh, supra note 72. 
driven by moral hazard and the pervasive derivatives deficit described in this Article. Second, credit risk is volatile and hard to measure. Scholars have argued that this type of risk can be hard to internalize, often defying models designed to capture its nuances. ${ }^{201}$ A party's credit profile can change quickly as panics ensue and losses grow larger. ${ }^{202}$ Scholars cite the difficulties in valuing the risk on structured products (for example, mortgage-backed securities) as one of the accelerants driving firm failures at the height of the 2008 financial crisis. ${ }^{203}$ Anecdotal evidence from the crisis provides ample evidence of these challenges. Professors Acharya and Taleb, surveying the fallout, have lamented the inability of industry models to capture adequately the infrequent but powerful risk events (or tail risks). ${ }^{204}$ AIG risk models, for example, provide startling evidence of failure by experts to forecast the volatilities of credit risk - and that failure's dire consequences. ${ }^{205}$ Though lessons learned from the crisis may enable us to better understand credit risk, this risk remains challenging and fickle. Given credit risk's systemic potency, the clearinghouse may require vast reserves of capital to protect itself. Keeping such reserves at a "fail safe" level ex ante is expensive and ultimately unprofitable for a clearinghouse. If members must provide large amounts of capital to the clearinghouse, their motivations to use the clearinghouse are likely to diminish considerably, leading them back to the dangers of the OTC markets.

Finally, the clearinghouse is an arena of complex games. These games are motivated by various member incentives, which may not all be directed toward reducing risk faced by the clearinghouse. As revealed in this Article, the clearinghouse is not always aware of how and to what extent it is being used by

201. Daniel G. Goldstein \& Nassim Nicholas Taleb, We Don't Quite Know What We Are Talking About When We Talk About Volatility, 33 J. PoRTFolı MGMT. 84 (2007); Benjamin Yibin Zhang et al., Explaining Credit Default Swap Spreads with Equity Volatility and Jump Risks of Individual Firms 1-3 (Bank for Int'l Settlements, Working Paper No. 181, 2005). In the industry, two models for credit-risk modeling came to prominence as the industry started to take off: J.P. Morgan's CreditMetrics and Credit Suisse Financial Product's CreditRisk. However, scholars have noted that both models often yielded different assessments of credit risk based on similar factual patterns. Debates regarding the extent to which such models can be reconciled continue and variability among models in this field is likely to persist. See Michael B. Gordy, A Comparative Anatomy of Credit Risk Models 1 (Bd. of Governors of the Fed. Reserve Sys., Fin. \& Econ. Discussion Series Paper No. 98-47, 1998).

202. Cf. Markus K. Brunnermeier, Deciphering the Liquidity and Credit Crunch 2007-2008, $23 \mathrm{~J}$. Econ. PERSP. 77 (2009) (discussing the spiraling effect that drops in asset prices can have on the broader financial markets).

203. Ralph Atkins et al., Regulation: Collateral Damage, Fin. Times, Oct. 24, 2012, http://www.ft.com/ intl/cms $/ \mathrm{s} / 0 / \mathrm{fb} 19 \mathrm{~d} 87 \mathrm{c}-1 \mathrm{~d} 12-11 \mathrm{e} 2$-abeb-00144feabdc0.html (discussing the challenge of valuing structured products and how this opacity makes it difficult for parties to set aside appropriate amounts of collateral).

204. Viral V. Acharya et al., Manufacturing Tail Risk: A Perspective on the Financial Crisis of 2007-2009, 4 Found. \& TRENDS IN Fin. 247, 247-48 (2010) (arguing that the financial crisis of 2008 was essentially a consequence of a shift in traditional risk taking among banks to the manufacture of tail risk which led to extreme exposure for the entire financial system); see also NASSIM NicHOLAS Taleb, The Black Swan: The Impact of the Highly Improbable (2d ed. 2010) (demonstrating the devastation that may be wrought by improbable but high-risk events that are often difficult to model).

205. Mollenkamp et al., supra note 187. 
members to trade risky contracts strategically. These games are intrinsic to the structure of the clearinghouse and render the institution more opaque. These games should be assumed to add a layer of risk to the institution's workings, without the clearinghouse being institutionally aware of the full picture. This means that the levels of capital demanded from members may be inadequate to support the levels of risk that they are taking. Taken together, the clearinghouse may find itself carrying hidden risks that crystallize in crisis without holding the protective buffers it needs when events go awry.

\section{Reconceptualizing the Paradigm: The Clearinghouse Reformed}

One of the central challenges noted in this Article relates to the financial market's widening gap between economic exposure and the legal rights and relationships that have traditionally framed that exposure. This section proposes a new and comprehensive regulatory solution to bridge this disconnect. This Article proposes that the clearinghouse gain stronger powers to (1) bridge information asymmetries; (2) gain a role in debt governance; and (3) check the incentive risks evidenced in reckless lending. With a strengthened legal hand, the clearinghouse will be better equipped to understand the depth of risk it assumes and, with that, the amount of protection it must keep to safeguard against its own collapse. In addition, through greater monitoring and a power to check incentive risks, it gains a channel through which it can exert discipline over a wider swathe of economic actors and thus reduce the levels of risk coming through its door.

Briefly stated, the clearinghouse channels credit risk from a variety of institutions. These include its members, first of all, but also others actors, such as nonmember financial institutions, and companies and entities whose debt may be referenced by the credit derivative. This Article suggests that because the CCP centralizes credit risk from this wide spectrum of sources, it should also gain broader legal rights to engage with this cohort of actors involved in credit extension and intermediation. This engagement would allow the clearinghouse to look beyond its members to seek out information on underlying exposures as well as to analyze and curb reckless behavior. It would also open the door for clearinghouses to push for greater presence in matters of debt governance where they have an economic stake in the insolvency of an underlying reference entity. It is not proposed here that clearinghouses commence trading with nonmembers but rather that they have the means to engage and communicate with this wider audience in order to garner better information on exposures, to exert greater discipline in lending, and to effectively assert an interest in debt governance if necessary. ${ }^{206}$

Using the analogy of the stag hunt, a reformed clearinghouse should provide

206. See Jeffrey Manns, Insuring Against a Derivatives Disaster (forthcoming 2012) (on file with author). Professor Manns provides a reform proposal with respect to the regulation of OTC derivatives, arguing for private gatekeeper-guarantors to monitor the risks of OTC derivatives. He argues that 
stronger motivation for participants to work towards the more optimal strategy of pursuing the stag rather than pursuing the hare for individual gain. More accurate information promotes better communication between members. Parties also face greater reputational pressures to align their conduct with the information received. With higher information flows, defection should become easier to spot. Furthermore, the prospect that bad conduct will be more easily revealed should encourage parties to behave in a manner conducive to overall societal gain, rather than to individual rewards.

\section{A. INFORMATION ASYMMETRIES}

Scholars across disciplines criticize the information asymmetries attaching to credit. $^{207}$ The clearinghouse is dangerously vulnerable to the costs of poor information collected by parties with only a limited stake in the game. These amplify where the clearinghouse must deal with derivatives referencing complex securities such as mortgage-backed securities that can suffer from deeply embedded informational deficits. ${ }^{208}$ Clearinghouses will benefit greatly from powers allowing them systematically to collect information on credit exposures from sources other than their direct members and thus to gain access to a far larger pool of data than they otherwise possess at present. With greater depth and breadth of information representing a wide cross section of the market, clearinghouses will gain a more accurate understanding of the underlying credit exposures they face, with the resulting gain in better institutional buffers against losses. At present, clearinghouses face high legal hurdles when obtaining information on underlying exposures from nonmember (and even member) actors. Legal challenges exist, for example, on issues of confidentiality, restrictions on data sharing and retention, liability for data accuracy on the part of a data provider, and cross-border controls on flows of personal information, all of which create barriers for clearinghouses that make it difficult for them to receive fulsome information on underlying debt. Although these challenges are, to varying degrees, inevitable, some clearing of a legal pathway to better information for the clearinghouse would be helpful. This should enable the clearinghouse to gain a broader understanding of the risks that it comes to bear as CCP and better calibrate the costs of these risks. The potentially negative impact of individual member firms' informational advantages also decreases as a result. Member firms are less able to optimize their informational advantages to undertake private rent seeking at the expense of the clearinghouse.

Still, the clearinghouse faces a tough task. One important question is whether

reinsurers should act as gatekeeper-guarantors for this market-and should have skin in the game by retaining a sliver of risk from each derivative trade that players in the derivative market enter into.

207. See, e.g., Levitin, supra note 38; Hernando de Soto, Editorial, The Cost of Financial Ignorance, WASH. Post, Oct. 7, 2011, http://www.washingtonpost.com/opinions/the-cost-of-financial-ignorance/2011/ 10/03/gIQAEU3yTL_story.html.

208. See supra section III.A.3 (discussing information defects associated with poor recordkeeping or incomplete data). 
the clearinghouse should be mandated to collect as much information as it can to match the exposures it is taking on as CCP, or whether it should do so voluntarily as a matter of best practice. One argument in favor of imposing a positive obligation in this regard comes from the centrality of clearinghouses to the market, epitomizing "too big to fail," and being likely to unleash systemic catastrophe in case of failure. Despite the Dodd-Frank Act's theoretical aversion to providing bailouts for clearinghouses ${ }^{209}$ the collapse of a clearinghouse is likely to create significant costs for taxpayers. In light of these costs, placing an ex ante burden on clearinghouses to protect their own interests makes sense and can potentially reduce the extent of ex post liabilities for the state and the market. Still, caution is important. There remains the case where clearinghouses face too high of a cost to operate and then pass these costs onto market players to the point where market players may find it more cost-effective to transact in darker, more complex OTC markets.

Guidance from regulation of other industries, such as insurance, may be useful in optimizing a model of the clearinghouse. Scholars argue that, in this area, companies' tasks are facilitated by a high degree of standardization across insurance contracts, such as automobile- or health-insurance agreements. ${ }^{210}$ This standardization makes it easier to mandate and populate data fields. The Dodd-Frank Act may be helpful to clearinghouses in this regard. First, the Act requires that there be greater standardization of credit-derivative contracts to allow them to be centrally cleared and traded on exchanges. ${ }^{211}$ In addition, the

209. The Dodd-Frank Act allows clearinghouses limited access to the Federal Reserve's discount borrowing window under exigent circumstances. See Dodd-Frank Act $\S \S 803(6)$ (A), 806(b) (codified at 12 U.S.C. $\$ \S 5462,5465$ (2006 \& Supp. V)) (authorizing the Federal Reserve Board to provide designated financial-market utilities, as defined under $\$ 803(6)(\mathrm{A})$, with discount and borrowing privileges "only in unusual or exigent circumstances"). Thus, even if a clearinghouse faces a significant liquidity crunch, clearinghouses are effectively restricted from obtaining emergency liquidity under the Federal Reserve's authority to lend under $\$ 13(3)$ of the Federal Reserve Act of 1913 . This authority was used, for example, during the AIG bailout as well as in many other instances where the provision of emergency liquidity was necessary. Subsections 1101(a)(2) and (a)(6) of the Dodd-Frank Act require the Federal Reserve Board to establish an emergency facility only where it may be generally available to a class of institutions and not to a particular financial institution that happens to be failing. See Dodd-Frank Act $\$ \S 1101(\mathrm{a})(2)$, (6) (codified as amended at 12 U.S.C. $\$ 343$ (2006 \& Supp. V)). In theory, this is likely to prevent a failing clearinghouse from accessing an emergency bailout under $\S 13(3)$ of the Federal Reserve Act. Indeed, $\$ 716$ of the Dodd-Frank Act categorically bans swaps entities from accessing the discount window and receiving any federal assistance. See Dodd-Frank Act $\S 716$ (a) (codified as amended at 15 U.S.C. $\$ 8305$ (2006 \& Supp. V)). However, clearinghouses benefit from certain exemptions to that rule: section 806 , in particular, authorizes Federal Reserve Banks to provide clearinghouses with "discount and borrowing privileges" "only in unusual or exigent circumstances." See Dodd-Frank Act § 806(b) (codified as amended at 12 U.S.C. $\$ 5465$ (2006 \& Supp. V)); Kress, supra note 116, at 88-89 (arguing that CCPs must have access to central-bank liquidity given their systemic importance and that Dodd-Frank's provision for access to credit in emergency circumstances is better than nothing).

210. Pierre-André Chiappori \& Bernard Salanié, Testing for Asymmetric Information in Insurance Markets, 108 J. PoL. ECON. 56, 57 (2000) (stating that insurance contracts are good data samples owing to the high degree of standardization among different types of insurance contracts).

211. Dodd-Frank Act $\$ 723$ (codified as amended at 7 U.S.C. $\$ 2(\mathrm{~h})(1)($ A) $(2006 \&$ Supp. V)). 
Act proposes some new innovations, including a requirement that members retain an audit trail of transactions, ongoing information on counterparties, and trade reports. ${ }^{212}$ This record keeping is designed to allow for transactions to be reconstructed. That being said, clearinghouse members' records may be colored by their respective standards of diligence and individual motivations. To compensate, the clearinghouse would benefit from direct access to information besides just the transaction trails of its members.

Government Sponsored Entities (GSEs) such as the Federal National Mortgage Association (Fannie Mae) and Federal Home Loan Mortgage Corporation (Freddie Mac), also have useful databases that may contain relevant information on clearinghouse members. These two GSEs purchase large numbers of loans from lenders and are active in the securitization market. ${ }^{213}$ The GSEs stipulate guidelines for lenders that set forth conditions on which, for example, GSEs purchase mortgages. These guidelines include requirements as to borrower creditworthiness and property information. ${ }^{214}$ Commentators note that the GSEs have often been persuasive in disciplining lenders. ${ }^{215}$ GSEs should retain records of lender compliance with applicable guidelines, if not of the underlying borrower data. Under the Dodd-Frank Act, originators and issuers in the securitization process are required to mark underlying assets with unique identifiers. ${ }^{216}$ If done correctly, these identifiers should make it easier to trace the trail of underlying transactions.

In addition, it may be worth contemplating whether clearinghouses would also benefit from access to government-agency databases, such as those of the Consumer Financial Protection Bureau (CFPB), the Federal Reserve, and the Securities and Exchange Commission (SEC). Internalizing all of this aggregate data is a tall order. Still, better information on underlying exposures should permit the clearinghouse to develop more effective models and analyze its exposures to sectors, geographical areas, and borrowers. From an ex post perspective, where the clearinghouse is required to pay up, it should be able to trace the deeper transactional trajectory more accurately.

Given the complex and often problematic incentives of clearinghouse members, it is imperative that the clearinghouse be subject to tough and independent audits of its information reservoirs and data-analysis policies. The Dodd-Frank Act mandates that the clearinghouse provide data on its internal procedures and practices to regulators and maintain good records as part of its internal gover-

212. Id. § 731 (codified as amended at 7 U.S.C. $\S 6 s$ (2006 \& Supp. V)).

213. See Michael Simkovic, Competition and Crisis in Mortgage Securitization 31 (Working Paper, 2011), available at http://papers.ssrn.com/sol3/papers.cfm?abstract_id=1924831 (noting that GSEs have had more conservative underwriting standards).

214. See Selling \& Servicing Guides, FanNIE MAE, https://www.efanniemae.com/sf/guides/ssg/ (last visited Oct. 15, 2012).

215. See, e.g., Lynnley Browning, New Lending Guidelines from Fannie Mae, N.Y. Times, Nov. 18, 2010, http://www.nytimes.com/2010/11/21/realestate/21mort.html; see also Simkovic, supra note 213, at 21-24 (noting that GSEs have been important in disciplining lenders).

216. Dodd-Frank Act $\S 942$ (codified as amended at 15 U.S.C. $§ 77 \mathrm{~g}(\mathrm{c})(2)(\mathrm{B})(2006$ \& Supp. V)). 
nance structure. ${ }^{217}$ However, tougher disclosure and monitoring requirements beyond those proposed under the Dodd-Frank Act may be desirable to examine the information-gathering and analytical methods of the clearinghouse. ${ }^{218}$ Just as federal and state bank examiners routinely visit banks to monitor compliance, the clearinghouse would benefit from proactive, engaged oversight of its internal trading and governance practices. Under this proposal, regulators would decide the design, structure, and frequency of these audits, ensuring, most of all, that these audits are sufficiently stringent to match the complex array of risks faced by the clearinghouse. Given the systemic valence of the clearinghouse's activities, their concentration, and the complex information flowing through it, it would be helpful if regulatory-audit committees were comprised of not only domestic regulators (such as the SEC and the Federal Reserve), but also industry experts, academics, and, potentially, representatives from international regulatory bodies such as the International Monetary Fund (IMF), who are regularly called upon to scrutinize the implementation of international-bestpractice standards for clearinghouses. ${ }^{219}$

Questions remain regarding the types of entities with which a clearinghouse should engage to collect information. One can assume these should not directly include individual, retail borrowers such as homeowners, students, and smallbusiness entrepreneurs. However, it seems reasonable to imagine that financial firms such as banks, investment or mortgage companies, broker-dealers, and various types of funds, as well as the large corporations (companies listed on NYSE/NASDAQ, for example), could directly provide more useful and complete information to the clearinghouse. Such users of financial services routinely disclose information, for example, to regulators or to exchanges. ${ }^{220}$ Allowing

217. Id. $\S 725$ (codified as amended in scattered sections of 7 U.S.C.).

218. Under $\S 725$ of the Dodd-Frank Act, clearinghouses have discretion with respect to how they establish internal-governance mechanisms, risk-management procedures, and default rules. DoddFrank Act $\S 725$ (codified as amended at 7 U.S.C. $§ 7 \mathrm{a}-1$ (i)(F) (2006 \& Supp. V)).

219. The International Monetary Fund and the World Bank are responsible for monitoring how international financial standards are incorporated into national regulatory systems. They carry out these assessments under the purview of the G-20 and the Financial Stability Board (FSB). One of these standards includes how countries' payment and settlement systems comply with international best practices regarding their regulation, as promulgated under the CPSS/IOSCO's Recommendations for Securities Settlement Systems \& Recommendations for Central Counterparties. Given the burgeoning role of the IMF as an overseer of global financial stability and clearinghouses' contribution to international systemic risks, its involvement in audits may be very helpful. Professor Brummer provides a helpful analysis of this program and related issues. Chris Brummer, How International Financial Law Works (and How It Doesn't), 99 Geo. L.J. 257 (2011); see also Chris BRUMmer, Soft LAW AND THE Global Financial System: Rule Making in the 21st Century (2012) (providing an important account of the role of the World Bank and IMF as "enforcers" of international standards, such that these standards exert greater coercive bite owing to this monitoring and assessment by these two institutions).

220. E.g., FINRA Rules, FINRA, rr. 4520-24, available at http://finra.complinet.com/en/display/ display_viewall.html?rbid $=2403 \&$ element_id $=8773 \&$ record_id $=12001$ (establishing reporting requirements broker-dealers must submit to FINRA); NYSE Listed Company Manual, NYSE, r. 203.01, available at http://nysemanual.nyse.com/LCMTools/PlatformViewer.asp?selectednode $=$ chp $\% 5 \mathrm{~F} 1$ $\% 5 \mathrm{~F} 3 \% 5 \mathrm{~F} 3 \% 5 \mathrm{~F} 1 \&$ manual $=\% 2 \mathrm{Flcm} \% 2 \mathrm{Fsections} \% 2 \mathrm{Flcm} \% 2 \mathrm{Dsections} \% 2 \mathrm{~F}$ (requiring all companies listed on the exchange "that [are] required to file with the SEC an annual report that includes audited 
the clearinghouse to engage more directly with these firms reduces the incidence of data loss through chains of intermediaries and gives the clearinghouse the means to tailor data requests.

\section{B. DEBT GOVERNANCE}

Without legal standing to intervene in proceedings by virtue of its economic interest, the clearinghouse loses the ability to seek capital-efficiency gains through the insolvency process. ${ }^{221}$ This Article proposes that, where the clearinghouse is identified as holding real economic exposure, it should be permitted to appear at the creditor's table and assume the rights of original bondholders or lenders. For example, if a clearinghouse is forced to pay out on a CDS where an underlying entity on whose debt a swap is written, then the clearinghouse should be permitted to assert an interest to recoup losses in insolvency proceedings. As detailed in Part III, this standing is likely to be most useful in cases of systemic crises where widespread market failure leaves the clearinghouse holding economic exposures on a broad swath of underlying reference entities. This standing is useful for three reasons: (1) it allows for the clearinghouse to attempt a recovery of amounts paid; (2) in a restructuring context, it provides the clearinghouse with a say in how an entity restructures its operations to regain profitability; and (3) it formally recognizes the clearinghouse's economic interest in the underlying debt and allows the clearinghouse to assert this interest in insolvency proceedings.

Again, practices in the insurance industry provide guidance in this case. Insurers commonly rely on the concept of subrogation to recoup sums paid out to an insured. Subrogation - understood as "standing in the shoes of another",222 allows insurers to assume some of the legal rights belonging to the insured, permitting the insurer to make a claim against the wrongdoer that caused the insurable loss. The ability of the clearinghouse to use a form of subrogation in the credit-derivative market may be helpful in mitigating some of the potential losses a clearinghouse might suffer. How subrogation should work in the context of the clearinghouse requires analysis. For example, a lender who receives payment on a CDS may still have an ongoing economic interest in the debtor if the lender only bought protection on part of its loan under the CDS. In such cases, the clearinghouse's and the lender's perspectives on how to treat the debtor during insolvency may diverge. Nevertheless, retaining legal rights to recoup some of what it pays out in insolvency is a small order for a systemic institution on the level of the clearinghouse.

financial statements (including on Forms 10-K, 20-F, 40-F or N-CSR) ... to simultaneously make such annual report available to shareholders of such securities on or through the company's website").

221. See Hu \& Black, Equity, supra note 25, at 728-29.

222. BlacK's Law DictionaRY 1467 (8th ed. 2004) ("The substitution of one party for another whose debt the party pays, entitling the paying party to rights, remedies, or securities that would otherwise belong to the debtor."); 73 AM. JUR. 2D Subrogation $\$ 1$ (2007) ("'Subrogation' is broadly defined as the substitution of one person in the place of another with reference to a lawful claim or right."). 
Further, how early should a clearinghouse intervene? In Part III, this Article offered the scenario of two direct members of a clearinghouse that start to get into trouble, while the underlying reference entity-Company $C$-stays in working order. If $C$ starts incurring losses, knowing that its lender is about to collapse, should the clearinghouse (rather than one of the member banks) call a creditors' meeting or otherwise have the power to suggest debt counseling or restructuring? And how quickly should it step in? Arguably, the response varies by scenario. Where there is a high likelihood of $C$ driving itself into disrepair, the clearinghouse may usefully act with legal tools (for example, to push for a Chapter 11 restructuring) to pressure underlying entities to behave better. Again, the policy value of this is not limited to protecting the systemic soundness of the clearinghouse. Rather, there is a broader aim to assure more robust underwriting and credit-allocation standards in the market.

One question remains: what use are these legal rights in the case of purely speculative, "naked" swaps, where traders do not own the underlying asset? One perspective may be that legal standing to assert an interest in debt governance has little benefit in such cases. For one, the value of the swaps written on an asset may far exceed the value of the asset itself. And, derivatives traders themselves may not have any meaningful legal standing vis-à-vis an underlying borrower, where their swap is purely speculative. Here, the derivatives trader may have no relationship to the borrower and may not even wish to invest in such a legal relationship to reduce its credit risk.

In actuality, however, the converse applies. The prevalence of speculative, naked swaps in the market significantly amplifies the case for clearinghouses to possess meaningful debt governance and monitoring rights to reduce their own institutional exposure. Fundamentally, from the perspective of risk management, the clearinghouse as $\mathrm{CCP}$ faces potentially catastrophic exposure on naked swaps; with this, its need for strong monitoring and debt governance tools is rendered all the more critical.

In a market that comprises only hedgers-meaning, CDS traders that own the underlying risk - the CCP can be sure that the amount of its own exposure is limited to the value of the debt issued by an underlying borrower. However, in a market with naked, speculative swaps, the clearinghouse's exposure can be much greater: the open interest on the CDS can far exceed the value of the underlying debt in issue owing to the presence of naked swaps. ${ }^{223}$ In a crisis, the CCP can thus face liability that is several-fold higher than in cases where hedgers dominate the market. With this gravity of risk, the clearinghouse is arguably best positioned to take preemptive steps through monitoring and debt governance to control its own overall exposure. Importantly, as $\mathrm{CCP}$, it should

223. For example, Delphi, an automotive company, had approximately $\$ 28$-billion worth of CDSs outstanding against \$5.2-billion worth of its bonds and loans when it entered bankruptcy in 2005. Satyajit Das, The Credit Default Swap ("CDS") Market-Will It Unravel?, WILMotT (May 30, 2008, 7:23 AM), http://www.wilmott.com/blogs/satyajitdas/index.cfm/2008/5/30/The-Credit-Default-SwapCDS-Market-Will-It-Unravel. 
be best placed to determine the volume of swaps trading on an underlying reference entity, speculative or not. From this privileged standpoint, by intervening early and asserting an interest in the debt governance of an underlying debtor, the clearinghouse can exercise a modicum of control to prevent these losses from materializing and jeopardizing its own survival. Certainly, clearinghouses are not especially used to playing such a role, and may not even wish to do so given the transaction costs they must bear in the process (for example, to obtain information on an underlying entity, assume the risks of intervention, or develop substantive strategies in how it wishes to exercise its powers). Nevertheless, the potential for catastrophic losses that exists in a speculative swaps market necessitates a reconceptualization of the traditional clearinghouse paradigm. In light of the severity of the threat it faces, the question of whether a clearinghouse wishes to participate in debt governance or possesses the historical experience to do so, must come second to the bigger question of what it must do to preserve its own institutional integrity and systemic safety in the market.

\section{INCENTIVE RISKS}

In the derivative-transaction chain, there are limited private incentives to police risk. This begs the key question: if clearinghouses are left to absorb the externalities generated by this recklessness, what recourse do they have to subdue its worst consequences?

This Article argues for a proactive approach. Clearinghouses would benefit from tailored tools to match those available to a lender. In cases of borrower recklessness, a lender can take various actions: upon breach of a loan covenant, lenders can (1) accelerate the loan and demand immediate repayment; (2) order the debtor to reduce its level of leverage; (3) order the debtor to refrain from further borrowing (for example, through a negative pledge); and (4) seek information from a debtor's other creditors to decide how best to act. Aside from lenders, insurance companies also manage the costs of moral hazard arising with respect to a vast cross section of entities. They face moral-hazard costs created by insured entities, whose behavior and risk profile may become more reckless after entering into the insurance contract. ${ }^{224}$ To control moral hazard, insurers deploy a range of tools to protect their interests, including "no claims bonuses" for those who refrain from submitting claims under the policy, deductibles, requirements that parties take steps to mitigate their losses, regular inspection of insured property, and codes that insured entities must comply with in order to satisfy a claim. ${ }^{225}$

Clearinghouses could use similar tools to those used by lenders and insurance companies to control their risks. Clearinghouses can mandate explicitly that

224. Chiappori \& Salanié, supra note 210 , at 60 .

225. See Howard Kunreuther, Mitigating Disaster Losses Through Insurance, 12 J. RISK \& UNCERTAINTY 171, at 182 (1996). 
parties mitigate their losses, comply with guidelines as to underwriting of debt that apply to nonmembers as well as to members, or restrict entry to clearing services for those who engage in reckless behavior. Clearinghouses can financially penalize their members who offer reckless entities access to clearing by assessing fines against them. Clearinghouses may consider drawing up lists of good behavior to highlight the efforts of firms that observe high standards of conduct and diligence. Clearinghouses would benefit from this arsenal of tools by applying them to members as well as nonmembers, where possible, in an effort to mitigate moral hazard.

The network effects of this disciplining will be powerful. When the clearinghouse engages with a nonmember bank that is making reckless loans, this intervention will affect that lender's volume and flow of securitizations in the market. Other lenders will seek to avoid similar reproach and will restrain their own conduct. Fewer securitizations or securitizations that reference better quality assets will result, which will serve as a benefit for investors in that this may also reduce the amount and riskiness of credit derivatives.

These are speculative propositions and many questions remain. What kinds of powers should a clearinghouse have? Governance concerns and conflicts of interest have driven legislators to enact $\S 765$ of the Dodd-Frank Act, which responds to worries that clearinghouses may act opportunistically to oust rivals from the market or be captured by their most powerful interests. ${ }^{226}$

\section{LINGERING DOUBTS}

This Article proposes that the clearinghouse be given legal devices to complement the economic exposures that it is assuming. Credit derivatives separate the economic interest in debt from the bundle of rights that attach to that interest. This separation results in numerous inefficiencies in how credit is allocated, as discussed throughout this Article. The proposal put forward in this Article seeks to remedy this basic separation by better matching legal rights to economic risk in the clearinghouse, thereby reducing the externalities and inefficiencies the separation generates.

But challenges remain. The first comes from the institutional imperfections afflicting the clearinghouse. As discussed in Part II, the clearinghouse subsidizes the trading activities of its members and potentially induces moral hazard. Mutualization diffuses and distributes risk but it also encourages firms to act opportunistically, even where this imposes high costs on the collective group of clearinghouse members. Granting additional powers to this risky institution appears counterintuitive and possibly even dangerous-clearinghouse members may game these new legal tools, for example, to garner information on rivals or unfairly extract rents from competitors seeking to use clearinghouse services.

However, these concerns ignore a broader point. The clearinghouse will fall

226. See Dodd-Frank Act $\S 765$ (codified at 15 U.S.C. $\S 8343$ (2006 \& Supp. V)) (authorizing the SEC to promulgate rules on control of, or voting rights with respect to, clearing agencies). 
under greater scrutiny on account of these added powers. This scrutiny will come from regulators and the market, in general. Private actors, banks, investment banks, and mutual or other funds are especially likely to ensure that clearinghouses do not misuse their powers. Where clearinghouses use their new powers improperly - for example, to give clearinghouse members an unfair advantage vis-à-vis their competitors-they face the prospect of soft discipline from those that use their services. In short, these private actors can take their business elsewhere. Additionally, in view of the private-rather than publicnature of the clearinghouse, members may be particularly sensitive to critique from peers. Regulators, too, will come under pressure to ensure the proper functioning and governance of the clearinghouse in view of the broader functions that the clearinghouse performs. Thus, a range of scrutiny from both the market as well as regulators will act as a disciplining force to push the clearinghouse to act in a manner that is less captured by strategic incentives.

A second concern is that the clearinghouse, holding these new powers, will start to look like a regulator itself. This actor underwrites swathes of market risk, obtains sensitive information on different classes of actors, and engages with market actors and regulators. This makes the clearinghouse not only an essential public good but also an actor that is too critical to fail. ${ }^{227}$ Actors in the financial markets are subject to a variety of overlapping and confusing legal regimes. ${ }^{228}$ The U.S. financial-regulatory system is notoriously fragmented, divided between several state and federal agencies with often duplicative jurisdictions. ${ }^{229}$ This does not change under the Dodd-Frank Act. Although the Dodd-Frank Act creates a new body-the Financial Stability Oversight Council-to exercise a modicum of consolidated oversight, it does not alter the basic underlying regulatory framework, which remains highly fragmented and duplicative. . $^{230}$

By contrast, the clearinghouse provides a simpler and more appealing formatone (under this Article's proposal) that is able to engage with a wide cohort of

227. Clear and Present Danger, supra note 2.

228. For a thoughtful account of the strategies and devices deployed by financial regulators, see Eric J. Pan, Understanding Financial Regulation 22-42 (Benjamin N. Cardozo Sch. of Law, Jacob Burns Inst. for Advanced Legal Studies, Working Paper No. 329, 2011). Professor Pan explores the effectiveness of the regulatory strategies deployed by regulators and, within this taxonomy, examines the effectiveness of regulators delegating oversight to private actors. Delegation to private actors-as opposed to regulating directly—can be driven by resource constraints faced by regulators. Additionally, Professor Pan analyzes the application of these strategies within the "sine curve" of regulation-that is to say, the cyclical tendency of regulators to regulate more heavily after crises than during periods of prosperity. See also Howell Jackson, Variation in the Intensity of Financial Regulation: Preliminary Evidence and Potential Implications, 24 YALE J. ON REG. 253, 281-86 (2007) (illustrating the difficulties of comparing national regulatory strategies by examining the high regulatory costs expended by U.S. regulators when compared to other regulators like the U.K.'s Financial Services Authority and exploring the implications of these differences for the fragmented regulatory architecture in the United States).

229. See, e.g., CCMR REPORT, supra note 19, at ES-31 to ES-34.

230. See Dodd-Frank Act $\$ \S 111-123$ (codified at 12 U.S.C. $\$ \S 5321-5333$ (2006 \& Supp. V)) (establishing Financial Stability Oversight Council). 
actors over many categories. Market actors would likely prefer to deal with a clearinghouse that not only provides some consolidated oversight, but also exerts soft discipline as part of its supervisory responsibilities, rather than subjects its charges to public and permanent sanction. The significance of the clearinghouse coming to be perceived as a de facto regulator is hard to overstate. And it raises a critical issue: as noted earlier, this institution is beset by problematic incentives and divided loyalties. However, despite the potential for the clearinghouse to be used by its members for private gains, it nevertheless performs an essential market function to reduce the counterparty risks inherent to securities trading. These competing pressures on the clearinghouse necessitate that the institution must be subject to scrutiny. Disciplining checks and balances are essential to the safe functioning of the clearinghouse (and the credit market more broadly) to reduce both the counter-party risk and the play of distorted incentives inhering within the clearinghouse structure. Though a discussion of the complex parameters of regulating the clearinghouse is beyond the scope of this Article, it is obvious that regulation and scrutiny of this institution are intrinsic to assuring that its credit-governance functions can be exercised optimally. The downside risks of regulatory failure in this regard are, needless to say, catastrophic.

\section{CONCLUSION}

The 2008 financial crisis has opened an analytical window into the flow of credit and its commoditization through credit derivatives and securitization. The dark side of these innovations exhibited itself amply through the market collapse and the prolonged economic devastation in the years following the crisis. The establishment of the clearinghouse is designed to fortify the market against the ill effects of financial innovation in the credit-derivative market. It should mutualize risk and make market players share losses. However, this Article argues that the design of this institution is problematic-and this is exacerbated by the fact that the credit-derivative products it trades are complex and tricky. This Article raises a number of new and underexplored risks regarding the interplay between credit-derivatives and clearinghouses to showcase that the clearinghouse faces regulatory and economic risks with which it is unfamiliar and for which it is ill-equipped to mitigate. These risks trace their origins to the fractured nexus between economic risks and the legal tools and techniques that have traditionally tamed those risks. This Article offers a normative proposal to reduce the negative externalities generated by these new challenges, premised on repairing this broken nexus. As the brave new world of central clearing of credit derivatives comes of age, the clearinghouse solution, while risky in its own right, presents an opportunity to protect the market as well as the taxpayer. With a closer nexus between economic risks and their complements in the legal toolkit, this institution may be co-opted to protect not just itself, but also the broader society against flights of reckless financial fancy that have the potential to take us back into the abyss at any moment. 